\title{
De hulpverlening in de spagaat tussen autonomie en afhankelijkheid
}

Citation for published version (APA):

van Eijk, J. T. M. (2000). De hulpverlening in de spagaat tussen autonomie en afhankelijkheid. Universiteit Maastricht. https://doi.org/10.26481/spe.20000630jte

Document status and date:

Published: 30/06/2000

DOI:

10.26481/spe.20000630jte

Document Version:

Publisher's PDF, also known as Version of record

\section{Please check the document version of this publication:}

- A submitted manuscript is the version of the article upon submission and before peer-review. There can be important differences between the submitted version and the official published version of record.

People interested in the research are advised to contact the author for the final version of the publication, or visit the DOI to the publisher's website.

- The final author version and the galley proof are versions of the publication after peer review.

- The final published version features the final layout of the paper including the volume, issue and page numbers.

Link to publication

\footnotetext{
General rights rights.

- You may freely distribute the URL identifying the publication in the public portal. please follow below link for the End User Agreement:

www.umlib.nl/taverne-license

Take down policy

If you believe that this document breaches copyright please contact us at:

repository@maastrichtuniversity.nl

providing details and we will investigate your claim.
}

Copyright and moral rights for the publications made accessible in the public portal are retained by the authors and/or other copyright owners and it is a condition of accessing publications that users recognise and abide by the legal requirements associated with these

- Users may download and print one copy of any publication from the public portal for the purpose of private study or research.

- You may not further distribute the material or use it for any profit-making activity or commercial gain

If the publication is distributed under the terms of Article $25 \mathrm{fa}$ of the Dutch Copyright Act, indicated by the "Taverne" license above, 


\section{De hulpverlening in de spagaat tussen autonomie en afhankelijkheid}

Jacques Th.M. van Eijk

Inaugurele rede

In verkorte vorm uitgesproken bij de aanvaarding van het ambt van Hoogleraar Medische Sociologie.

30 juni 2000

door

Prof.dr. J.Th.M. van Eijk 



\section{De hulpverlening in de spagaat tussen autonomie en afhankelijkheid}

\section{Inleiding}

In het najaar van 1998 werd ik uitgenodigd te verschijnen voor de sollicitatiecommissie ten behoeve van de vacante leerstoel Medische Sociologie. Van deze commissie maakte, zoals gebruikelijk ook een student deel uit. Uiteraard werden er de gangbare vragen gesteld over mijn wetenschappelijke prestaties en managementervaring. Het student-lid van de commissie stelde vragen van een geheel andere orde, maar zeker niet van minder belang. Begrijpelijkerwijze gingen haar vragen primair over het aandeel van de Medische Sociologie in de opleiding. Zo kan ik mij herinneren dat de betreffende studente mij de vraag voorlegde: "Als ik straks als medicus te werk gesteld ben, wat heb ik dan bij de uitoefening van mijn vak aan de medische sociologie." Ik kan u zeggen dat ik met het antwoord op deze op zich zelf voor de hand liggende vraag. behoorlijk wat moeite had. Ik meen mij te herinneren dat ik iets mompelde van "de plaats van de zieke in diens sociale context. Ondat ik het als een noodzaak zie voor een opleiding als de geneeskunde wetenschappelijke abstracties concreet hanteerbaax te maken voor het dagelijks handelen wil ik vandaag, nu ik er wat meer over heb kunnen nadenken, een poging wagen een wat specifieker antwoord 
te geven op de destujds gestelde wraag. Zoals de titel al aangeeft zall dat antwoord te maken hebben met de gerelateerde kwesties van autonomie en afhankelijkheid. Ik heb niet de pretentie dat ik een definitief antwoord kan geven. Immers de gezondheidszorg is sterk in ontwikkeling en mogelijke antwoorden op de gestelde vraag resoneren mee met deze veranderingen.

De hulpverlening van vandaag verkeert om diverse redenen in een moeilijke positie. Vergrijzing en de resulterende toename vari het aantal mensen met een chronische aandoening hebben het dillemma van de kewze tussen bevordering van autonomie en professionele dominantie prominent op de agenda gezet. Dat dilemma is niet nieuw. Immers de arts-patient-rellatie is een klassiek thema binnen de Medische Sociologie. Relatief nieuw zijn wel huidige opvattingen over autonomie in de hulpverlening.

In mijn oratie wil ik ingaan op enkele woor het thema relevante demografische veranderingen en daaraan gerelateerde veranderingen in het morbiditeitpatroon. Daarnaast zal ik kort enkele ontwikkelingen binnen de gezondheidszorg behandelen. Deze veranderingen drukken de hulpverlening als het ware verder in zijin benarde positie, waardoor respect voor autoriomie in het gedrang kan komen.

Als de hulpverlening door alle veranderingen onvoldoende toe kan komen aan de geëigende zorg voor chronisch zieken, is de vraag aan de orde welke rol chronisch zieken zelf kunnen spelen bij het zoeken van de optimale balans tussen autonomie en afhankelijkheid. Eerr mogelijkheid daartoe is zelfmanagement. De ontwikkelingen op dat terrein zal ik kort de revue laten passeren. Ten slotte zal ik aangeven hoe ik aan die ontwikkeling als medisch socioloog een bijdrage denk te kunnen leveren.

\section{Autonomie en afhankelijkheid: een plaatsbepaling}

Het begrip autonomie heeft in de medische ethiek de afgelopen decennia de nodige ontwikkeling doorgemaakt. Gold vroeger het Hippocratische adagium van "weldoen desnoods zonder de patiënt of zelfs tegen diens wil", vanaf 
de jaren 60 was het gedaan met het paternalisme. De ontwrikkeling van de medische technologie zorgde voor nieuwe ethische dilemma's toen het mogelijk werd het leven kunstmatig te verlengen. De paternalistische dokter moest plaats maken voor de dokter met respect voor de autonomie van de patiënt.

Autonomie wordt opgevat als de onafhankelijkheid van patiënten bij beslissingen over wat er met hun gezondheid gebeurt. Autonomie is het recht om te kiezen zonder inmenging. Dat kan variëren van de zelfstandigheid bij de beslissing tot het inroepen van hulp tot het zelfstandig kunnen bepalen of een preventieve, diagnostische of therapeutische (be)handeling wordt ingezet. Het betreft met andere woorden de intentie en het verrnogen om te reflecteren op de keuzes die mogelijk zijn ten aanzien van het voorkómen of oplossen van een gezondheidsprobleem door de patiënt zelf (1). Het gaat daarbij niet primair om de inhoud van de uiteindelijke beslissing zelf maar om de manier waarop die tot stand komt. Het ontbreken van autonomie impliceert in deze opvatting afhankelijkheid van anderen bij beslissingen over keuzes. Zo kan er in het geheel geen sprake zijn van autonomie in geval van wilsonbekwaamheid of bewusteloosheid en is er dus sprake van volledige afhankelijkheid. Deze opvatting van autonomie geldt in onze samenleving als een werworven recht dat als zodanig ook in de wetgeving is terug te vinden en het is dan ook bijvoorbeeld een belangrijk element bij de beoordeling van de gang van zaken bij beslissingen rond het levenseinde (2). Het respecteren van autonomie houdt voor de hulpverlener in dat deze niet intervenieert in de besiuitvorming van de patient ten aanzien van de te maken keuzes, Uiteraard wordt de patiënt krachtens zijn recht volledig voorgelicht maar de uiteindelijke beslissing ligt bij de patiënt, die een welloverwogen beslissing neemt. Uitgangspunt is de rationaliteit en het recht op individuele keuzevrijheid (3). Er wordt in dit verband ook wel gesproken van negatieve vrijheid. Inperking van deze vrijheid leidt tot zijn tegenpool nl. afhankelijkheid(4). Patienten wordt in deze opvatting geen strobreed in de weg gelegd bij het kiezen van het te volgen beleid. 
Dat in een situatie waarin er medisch gezien weinig wirist meer te behalen is (bijv. un de terminale fase), beslissingen over behandeling primair bij patiènten en hun naasten worden gelegd, ligt uiteraard woor de hand. lets ingewikkelder wordt het indien een hulpverlener te maken heeft met een patiënt die zich wenst te ontrekken aan professionele zorg als er medisch gezien wel degelijk iets geboden kan worden. Nog lastiger wordt het als het zich ontrekken aan behandeling onderdeel van het gezondheidsprobleem is, bijy in gevall van een depressieve patiënt met hartfalen die weigert het medisch regiem te volgen. De arts heeft in dat geval immers een goede behandeling voor de depressie beschikbaar waarvan de kans op resultaat vrij groot is. Behandeling van de depressie kan vervolgens tot betere therapietrouw leiden die weer een positief effect heeft op de algehele gezondheidstoestand. Moet deze patient dan maar aain zijn lot overgelaten worden, omdat het nu eenmaal zijn eigen keuze is? In de ethiek heeft dit dilemma tot een herinterpretatie van het begrip autonomie geleid (5). Als een patiënt vanuit de hulpverlener gezien onvoldoende rekening houdt met de gevolgen van onttrekking aan behandeling, kan de hulpverlener ingrijpen met het doel de consequenties van onttrekking aan de orde te stellen en de patiënt in een soort onderhandelingsproces te overtuigen van de noodzaak tot behandeling. Uiteraard vereist dit nogal wat "negotiating skills" van hulpverleners. In dergelijke gevallen doet de hulpverlener zijn best om in interactie met de patiënt te komen tot een hulpverleningsplan dat er toe moet leiden dat de gezondheid van de patiënt verbetert. Dit op zijn beurt vergroot de magelijkheid de autonomie te herstellen. In de ethiek wordt in dit verband gesproken van positieve vrijheid. Anderen, zoals hulpverleners of mensen wit de primaire omgeving, zetten zich in voor bevordering van de autonomie van de patiënt. In deze opvatting gaan afhankelijkheid en autonomie dus hand in hand.

Autonomie krijgt nu immers alleen vorm in relatie met de inzet van anderen. De herinterpretatie van het autonomie begrip heeft geleid tot het inzicht dat artsen op grond van hun professionele voorsprong de keuzen van de patiënt kunnen trachten te beinvloeden met als doel de voorwarden te scheppen voor herstel van autonomie. Deze 
opstelling wordt opgevat als een manier om de autonomie van patienten te respecteren. Het is evident dat al te sterke overtuigingskracht al snel op paternalisme kan gaan lijken. Het verschil met een patemalistische opstelling zit hem echter in de interactieve component die in het biygestelde autonomie begrip ligt opgesloten. Immers een besluit komt in samenspraak tot stand.

In de nieuwe opvatting van autonomie gaat het derhalve niet alleen om een andere manier van beslissen, het gaat ook om wat besloten wordt. Dat betreft beslissingen over de zorg voor lichamelijke, geestelijke en sociale functies van de zieke, dus over de wijze waarop de functionele autonomie bevorderd wordt. Behoefte aan deze zorg impliceert per definitie uiteraard ook afhankelijkheid van personen uit de omgeving, zoals familie of de hulpverlening. De professionele hulp is daarbij primair gericht op de vermindering van deze afhankelijkheid en zo mogelijk bevordering of behoud van de functionele autonomie. Bij beslissingen over de te leveren zorg kan het accent op elk van de genoemde functies komen te liggen en niet uitsluitend op het fysieke element. zo kan in het geheel van aanpassingen die lemand met een chronische ziekte in het dagelijks leven moet maken, het accent komen te liggen op het leren omgaan met de ziekte in het dagelijks leven (gezin, werk). Welke zorg geleverd wordt is een uitonderhandeld compromis tussen hetgeen medisch wenselijk is en datgene wat nodig is voor een nieuwe balans in een lever met chronische ziekte.

De wijze waarop recht wordt gedaan aan het principe van respect voor autonomie is sterk van invloed op de aard van de relatie tussen betrokkenen. Zo kan de bereidheid van patiënten mee te werken aan maatregelen om het gezondheidsprobleem aan te pakken sterk negatief beinviloed worden door een al te paternalistische opstelling. (6) Niet voor niets laat een meta-analyse zien dat de bereidheid van chronisch zieken om mee te werken aan het medisch regiem zeker geen vanzelfsprekendheid is (7).

De herijking van het autonomiebegrip biedt cok vanuit medisch-sociologisch perspectief een interessante 
mogelijkheid om de besiuitvorming over de zorg aan chronisch zieken op een eigentijdse wijze inhoud te geven. In eer aantal opzichten heeft de arts eem professionele voorsprong op patiénten op grond van zijn medische kennis en ervaring, aan de andere kant zijn juist chronisch zieken zelf het best in staat de consequenties van hun ziekte en het medisch regiem voor het dagelijks leven te doorzien, ja zelfs aan den lijve te ervaren. De weging van die consequenties is afhankelijk van uiteenlopende voorkeuren van patiënten, de aard en de fase van de chronische ziekte.

\section{Demografische ontwikkelingen}

De huidige demografische ontwikkelingen hebben niet alleen een sterke invloed op de workload in de gezondheidszorg, maar ook op de aard van het morbiditeitpatroon.

\subsection{De levensverwachting}

Zoals bekend is de levensverwachting de afgelopen jaren toegenomen. Op dit moment bedraagt de levensverwachting van manneri en vrouwen bij de geboorte resp. 75,1 en 80,5 jaar (8). In ongeveer 40 jaar is dat een stijging van resp. 4 en 5 jaar. De stijging van de levensverwachting is vooral te danken aan terugdringing van de kindersterfte en de bestrijding van met name infectieziekten vóor 65 -ste levensjaar. Dat blijkt uit het feit dat de levensverwachting bij 65 jaar de afgelopen 40 jaar veel minder gestegen is: voor mannen eigenlijk nauwelijks en voor vrouwen drie jaar. Opmerkelijk is dat zowel in de levenswerwachting bij geboorte als op 65-jarige leeftijd vanaf 1990 een zekere stabilisatie optreedt.

Volgens berekeningen van het RIVM heeft de ongezonde leveinsverwachting (aantal jaren van je leven met ongezondheid) gelijke tred gehouden met de levensverwachting. Dit betekent dus dat de jaren die aan het leven zijn toegevoegd in ongezondheid worden doorgebracht. Daamaast stijgt het $\%$ ouderen vanwege de geboortegolf met ongeveer $25 \%$ in de komende 15 jaar (9). De lkomende jaren zal er dus als gevolg van de hogere levensverwachting en de toename van het aantal $65+$ ers een forse toename van het aantal personen met een chronische aandoening plaats vinden die 
gedurende een langere periode van het leven in ziekte doorbrengen. Niet alleen omdat de levensverwachting is toegenomen, maar ook omdat chronische ziekten steeds eerder zullen worden opgespoord. Van de belangrijkste chronische aandoeningen wordt een toename verwacht van $25-60 \%$ (10).

De gezondheidszorg wordt dus de komende jaren met meer chronische chronisch zieken geconfronteerd die ook nog over een langere periode ziek zullen zijn. Ervan. uitgaande dat de herijking van het autonomie begrip bij uitstek van toepassing is op de zorg voor chronisch zieken zullen de kwesties van autonomie en afhankelijkheid in de nabije toekomst veel sterker dan voorheen op de voorgrond komen te staan.

\subsection{Kenmerken van acute en chronische ziekten}

In de opleiding tot arts ligt het accent veelal nog steeds primair op een benadering van gezondheidsproblemen die het best past bij acute ziekten. Hetzelfde geldt voor de medische praktijk. Het accent ligt primair op het stellen van de diagnose, uitsluiten van ernstige ziekte en curatieve of symptoombestrijdende handelingen. Dit houdt vaak in dat pas handelend wordt opgetreden als de patient aan het loket verschijnt. De behandeling van patiënten met een chronische aandoening is gebaat bij een hele andere benadering. Maar artsen hebben te weinig geleerd om te differentiëren tussen een benædering welke past bij acute dan wel chronische aandoeningen. Het is dus van groot belang de verschillen tussen acute en chronische ziekten in het dagelijks handelen te verdisconteren. 
Schema 1

Verschillen tussen acute en chronische aandoeningen

Kenmerken Acute ziekten Chronische ziekten

$\begin{array}{lll}\text { beloop } & \text { kort } & \text { lang } \\ \text { oorzaak } & \text { belkend } & \text { onbekend } \\ \text { theraple } & \text { bekend } & \text { onbekend } \\ \text { follow-up } & \text { NVT } & \text { belangrijk } \\ \text { prognose } & \text { pos } & \text { neg } \\ \text { beleving } & \text { pos } & \text { neg }\end{array}$

Over oorzaak, beloop en therapie van infectie- en acute ziekten is relatief veel bekend. Bij chronische aandoeningen ligt dat anders. Van de meeste chronische ziekten is redelijk goed bekend wat het beloop is, maar ten aanzien van de therapie staat de geneeskunde veelal machteloos. In het beste geval is het mogelijk het ziekteproces af te remmen. Wel is bekend dat leefstijlfactoren mede een belangrijke rol spelen bij het ontstaan en het beloop van chronische ziekten, maar verandering van leefstijl ligt vanwege de sterke verankering in de sociaal-culturele context meestal buiten het directe bereik van de geneeskunde. Bij acute ziekten is een goede follow-up in de zorg en anticipatie op veranderingen in het beloop uiteraard veel minder aan de orde dan bij chronische ziekten. Zorg woor chronisch zieken impliceert per definitie een longitudinale/pro-actieve benadering. De ziekte-episode bestrijkt een lange periode en vereist voor adequate actie een longitudinaal beeld van hoe de ziekte zich ontwikkelt. Dit is alleen mogelijk als patiënten met een vaste regelmaat aan het loket van de hulpverlening verschijnen. Zonder die regelmaat komen chronisch zieken vaak pas op het spreekurur als het echt mis gaat met de gezondheid. Een meer op de longitudinale benadering en tijdige detectie toegespitste handelwijze kan bij verschillende chronische aandoeningen tot een mitigatie van het ziekteproces leiden en daarmee tot een afremming van de beperkingen in de functionele autonomie (11). Uiteraard is er ook per definitie meestal een belangrijk yerschil in prognose tussen acute en chronische aandoeningen. Vanwege de beschikbare therapieen is die bij acute 
ziekten vaak gunstig. Bij chronische ziekten kan het ziekteproces in het gunstigste geval afgeremd worden. Ten slotte is de emotionele beleving van het ziek zijn een ander belangrijk verschil tussen chronische en acute ziekten. Voor mensen met een acute ziekte is er waak hoop op snelle verbetering, terwijl chronisch zieken het woonuitzicht van een vernauwend levensperspectief hebben. Het voortdurend hervinden van een evenwicht met het voortschrijden van het ziekteproces en daaraan gerelateerde veranderingen in. de levensomstandigheden leidt vaak tot gevoelems van neerslachtigheid en depressie. Uit studies onder thuiswonende ouderen blijkt bij herhaling dat een aanzienlijk percentage van de ouderen met chronische ziekten relatief vaak depressieve werschijnselen heeft. Dit percentage ligt nog aanmerkelijk hoger als er sprake is van co-morbiditeit (meer dan één chronische ziekte). De laatste jaren wordt bovendien steeds duidelijker dat depressieve verschijnselen bij ouderen een eigen directe invloed op de gezondheid hebben (12). Zo is er een lineair verband aangetoond tussen de ernst vam depressieve verschijnselen en mortaliteit (13). Depressie verhoogt de kans cardiovasculaire mortaliteit aanzienlijk. Dit geldt niet alleen woor ouderen met (risico's op) cardiovasculaire morbiditeit, maar evenzeer voor ouderen zonder deze risico's (14). Hiervoor worden onder meer pathofysiologische veranderingen als gevolg van de depressie verantwoordelijk gehouden (15-17). Een andere mogelijke verklaring is gevonden in de relatief ongezonde leefstijl van depressieve personen, hetgeen bij chronisch zieken kan resulteren in een gebrekkige therapietrouw (18). Deze gegevens maken duidelijk dat in de hulpverlening aan chronisch zieken aandacht voor het emotionele aspect van het chronisch ziek zijn dient te worden ingeruimd.

Bij de 6 genoemde kenmerken bestaat er dus een verschil tussen acute en chronische aandoeningen. In het kader van mijn betoog is het verschil tussen chronische en acute ziekten wat betreft de mogelijkheden om de autonomie te respecteren, wellicht van nog groter belang. Bij acute ziekten is er per definitie relatief weinig ruimte voor reflectie. Bij een hartinfarct moet er doorgaans acuut gehandeld worden. Er zijn geen alternatieven voor onmiddelijke 
inzet van de professionele deskundigheid. Bij chronische ziekten ligt dat uiteraard anders. Het gaat dan immers om een blijvende en voortschrijdende ziekte, met een voor ouderen vaak geleidelijk aan afnemend levensperspectief, met voldoende tijd voor een goede afweging van de behandelingsaltematieven. Gegeven de kenmerken is de herijking van het autonomiebegrip bij uitstek aan de orde bij mensen met chronische ziekten. Vanuit de Medische Sociologie is overigens al veel eerder vastgesteld dat bejegening van patiënten mede afhankelijk is van de aard van het gezondheidsprobleem (19).

\subsection{Fasen in het beloop}

Gegeven de verschillende rol van hulpverleners in de verschillende fasen van het ziekteproces is het van belang ook te kijken naar de fasen in het beloop van een chronische ziekte. Chronische ziekten kunnen aanzienlijk verschillen wat betreft het begin (acuut of geleidelijk), het beloop (progressief, met exacerbaties of constant), de gevolgen (meer /minder invaliditeit, meer/minder last) en de mate waarin het leven bedreigd wordt. Deze verschillen in aanmerking genomen biedt het volgende schema (20-21) enig inzicht in de fasen in het beloop die bij elke chronische ziekte in meerdere of mindere mate en vroeger of later een rol spelen:

\section{Schema 2}

Fasen in het beloop van chronische ziekten

Crisis:

prediagnostische fase

diagnose

acceptatie fase

Chroniciteit:

stabilisatie fase

progressie fase

complicatie fase

Terminaal stadium: preterminale fase overlijden postterminale fase 
De ontdekking van een chronische ziekte is doorgaans een persoonlijke crisis die ook de primaire orngeving niet onberoerd laat. Is de diagnose eenmaal vastgesteld dan moet de chronisch zieke gaan leren leven met (de gevolgen van) de chronische ziekte en zal een nieuwe balans moeten worden gevonden.

In de fase van chroniciteit treedt aanvankelijk een stabilisatiefase in waarin geleidelijk aän een manier van leven met de chronische ziekte dient te worden gevonden. Vaak kan er voor langere tijd een balans gevonden worden. Er za] echter een moment aanbreken waarop progressie in het ziektebeeld optreedt met verergering van de klachten. In deze fase neemt de afhankelijkheid van medische en andere hulp toe. Uiteindelijk zullen er complicaties van de ziekte optreden of co-morbiditeit. Er is doorgaans een sterker appel op medische hulp, maar ook de afhankelijkheid van de primaire omgeving is sterk toegenomen. Patiënten zijn steeds meer gebonden aan huis, stoel of bed.

De laatste levensfase dient zich aan. In deze fase die overigens qua tijdsduur aanzienlijk kan verschillen tussen patiënten met verschillende en dezelfde chronische ziekte, wordt sterk geanticipeerd op hetgeen komen gaat, en zijn patiënten vaak bezig met het naderend levenseinde.

Desondanks is het overlijden zelf woor de directe omgeving een zeer emotionele fase, waaraan door de meest betrokken hulpverleners ook na het overlijden nog de nodige aandacht wordt besteed.

In alle fasen van het beloop van een chronische ziekte speelt respect voor autonomie een belangrijke rol, zij het met verschillende accenten. Met een geleidelijke afname van de lichaamsfuncties komt het accent van de hulpverlening steeds meer te liggen op de psychische en sociale aspecten Medische zorg wordt palliatie. Met een toename van de medische mogelijkheden wordt de lengte van de ziekteepisode opgerekt en zal de bemoeienis van hulpverleners zich dus over een langere ziekte-periode gaan uitstrekken. Dit geldt a fortiori woor hulpvragen en behoeften van patiënten in de complicatie- en de terninale fase. 


\section{Ontwikkelingen in de gezondheidszorg}

Everals in de samenleving als geheel voltrekken zich op dit moment ook in de gezondheidszorg in rap tempo ingrippende veranderingen. In het bestek van deze oratie zal ik mij moeten beperken. Dat de keuze op de 3 volgende onderwerpen is gevallen is toevallig.

\subsection{Ontwikkelingen in de informatietechnologie}

We maken op dit moment een srielle ontwikkeling van de informatietechnologie door. De verwachtingen zijn hoog gespannen. Ten aanzien van de zorg voor chronisch zieken is er zowel voor patiënten als hulpverleners belangrijke winst te boeken (22). De hulpverlener zal via automatische gegevens vastlegging (Elektronisch Medisch Dossier) veel beter in staat zijn het beloop van chronische ziekten in kaart te brengen dan tot nu toe. Dat heeft het belangrijke voordeel dat bij mensen met een chronische ziekte veel gemakkelijker pro-actief te werk gegaan kan worden. Ook is hij/zij veel beter in staat hiaten in de follow-up kontakten met zijn patiënten te signaleren en mogelijke noncompliance op te sporen. De techniek is er, maar geautomatiseerde data-opslag vereist een vorm van systematisch werken die veel hulpverleners zich nog eigen moeten maken. Van veel chronische ziekten zijn inmiddels richtlijnen voor diagnostiek, behandeling en follow-up door de betreffende beroepsgroepen vastgelegd. Omdat zij de professionele standaard vertegenwoordigen zall het format van de data-opslag dezelfde structuur krijgen. Hulpverleners worden door de geautomatiseerde vastlegging als het ware in het keurslijf van het protocol geperst. Dit vereist een behoorlijke gedragsverandering.

In de gevorderde fasen van het beloop zijn vandaag de dag diverse hulpverleners bij de hulpverlening betrokken. Zo heeft een patiënt met diabetes in de fase van complicaties soms wel met meer dan 6 verschillende hulpverleners te maken. Met de huidige internet toepassingen is het technisch mogelijk om de data van alle betrokken hulpverleners automatisch in het elektronisch dossier van de relevante hulpverlener terecht te laten komen, waardoor deze voortdurend overzicht heeft over de diagnostiek en 
behandeling wan alle bij de hulpwerlening betrokkenen. Aanshiting tussen de databestanden wait verschilende hulpvenleners op elkaar impliceert dat ook alle andere betrokken hulpwerleners of instanties die woor de zorg relevante data genereren dezelfde gedragsverandering moeten doomaken. Daarbij is het nog maar de vraag hoe de samenwerking en de overeenstemming over de takkverdeling tussen alle betrokkenen er uitziet. Met andere woorden: de organisatie van zorg dient op orde te zinn, met een heldere taakverdeling tussen alle betrokkenen en daarvan afgeleid: afspraken over informatie die uitgewisseld dient worden. Alle betrokkenen zullen onderdeel van een siuitend systeem dienen te zijn. Pas dan kunnen de technische mogelijkheden gevaluteerd worden.

Met behulp van internet kunner patiënten beter geinformeerd worden over hun ziekte of klachten. Een van de doelstellingen is patienten cen betere rationele afweging voor een bezoek aan de hulpvertener te laten maken, in de hoop dat onnodige kontakten vermeden worden. Maar wat is een onnodig contact indien het gaat om een pateuent met een chronische aandoening. Het gaat hierbij doorgaans immers niet (alleen) om behoefte aan informatie, maar vooral ook om behoefte a an begeleiding. In het algemeen zal de patient van de toekomst doorgaans beter geinformeerd de spreekkamer binnenstappen en daardoor ook over meer medische kennis over de ziekte beschikken.

Informatietechnologie kan de kwaliteit en de doelmathgheid van de hulpverlening aanzitenlijk verbeteren, maar de noodzakelijke omslag zal een forse inspanning en voorbereiding van betrokken hulpverleners vergen. Dit verhoogt de bestaande druk op de ketel extra. Het keurslijf van een gestructureerde benadering die bij het gebruik van geautomatiseerde dataopslag hoort, zet het streven naar een gedifferentieerde zorg voor de patiënt in de periode vant de omslag onder druk. Patiënten zullen beter geïformeerd worden over hun ziekte.

\subsection{De fragmentatie van de zorg}

Transmurale zorg, substitutie, practice redesign, costw containment, ketenzorg, zlekenhuisverplaatste zorg. 
thuiszorgtechnologie, managed care en diseasemanagement zijn verschillende benamingen voor pogingen om de zorg te verbeteren, doelmatiger te maken en tegelijkertijd dichter bij de mensen thuis te brengen. Uiteraard zijn het ook pogingen om te anticiperen op het nog steeds toenemende aanbod van gezond heidsproblemen (23), bij een groeiend tekort aan hulpverleners.

In de huidige gezondheidszorg valt een tendens te bespeuren om de oplassing voor de problemen in de gezondheidszorg te zoeken in toenemende differentiatie en specialisatie, buiten en naast de reguliere gezondheidszorg om. Het duidelijkste voorbeeld hiervan is te zien in de Amerikaanse gezondheidszorg, waar alle potentiele aanbieders van zorg, zoals bedrijven, farmaceutische industrie en ziektekostenverzekeraars zich betrekkelijk vrij op de markt van de gezondheidszorg kunnen bewegen. Deeltjes zorg voor dezelfde chronisch zieken worden door steeds meer verschillende hulpverleners of instanties aangeboden. Meestal hebben deze innovaties betrekking op de zorg in de stabiele fase van het ziekteproces. Het blijkt dat interventiestudies bij herhaling demonstreren dat gefragmentariseerde zorg in termen van medische uitkomsten en kwaliteit van leven effectief is voorzover het deel van de zorg omvat waarop de interventie betrekking heeft. Bij al deze succesvolle experimentele verbeteringen van de zorg komt de reguliere zorg, ook na afloop van het experiment, vaak buiten schot te staan, doordat bij de experimenten betrokken hulpverleners die taak overnemen van de reguliere zorgverleners, ook na afloop van het experiment. Pas in de fase van complicaties en verergering van de ziekte vallen patiënten veelal terug op hun oude vertrouwde "primary care givers". Deze primair op doelmatigheid gebaseerde innovaties die naast de bestaande hulpverlening om zijn opgezet, blijken uiteindelijk bij verergering van de ziekte niet meer te voldoen. De fragmentarisatie van de zorg leidt niet alleen tot een wreinig kosteneffectieve uitbreiding met deeltjes zorg naast de reguliere zorg, maar leidt in de fasen van verergering van het ziektebeeld bovendien tot een gemis aan vertrouwelijkheid dat zo nodig is bij toenemende afhankelijkheid (11). 
In de VS heeft de specialisatie en de daaruit woort vloeiende fragmentarisatie van de zorg de discussie aangewakkerd over de vraag of de zorg voor chronisch zieken nu primair ziekte-specifiek (elke ziekte zijn eigen specialisme) of generiek (alle ziekten behandeld door een generalist met zo nodig doorverwijzing naar specialist) zou moeten worden georganiseerd. Het idee hierachter is dat een heldere organisatie van de zorg en bundeling van alle expertise op het terrein van de betreffende chronische ziekte de zorg effectiever maakt. Hoewel er hier nog geen. Amerikaanse toestanden zijn, zien we ook in Nederland ontwikkelingen in deze richting, bijv in de vorm van ziektespecifieke centra zoals diabetescentra of de inzet van gespecialiseerde verpleegkundigen die weliswaar niet los maar dan toch wel onathankelijk van de reguliere zorg gaan opereren. Zowel wit oogpunt van kostembeheersing als van kwaliteit van zorg zijn Amerikaanse deskundigen ervan overtuigd dat deze innovaties veel beter een plaats kunnen krijgen binnen de reguliere zorg, in plats van kleinschalige ad hoc initiatieven buiten die zorg om. Dat zullen ook kleinschalige initiatieven blijven omdat hierbij veelal de steun van de "local authorities" ontbreekt en "opinion leaders" moeilijk overeenstemming kunnen krijgen over de beste reorganisatie van zorg. Hoe deze discussie hier in Nederland ook zal aflopen: bij patiënten bestaat, met name in de gevorderde fasen van hun ziekte sterke behoefte aan centrale coördinatie. De vraag is uiteraard wel of de reguliere hulpverlening deze taak, gezien de fors gestegen werkdruk zal kunnen (blijven) waamaken. Het gevaar bestaat dat bij een tekortschietende reguliere zorg, anderen dit "gat in de markt" gaan exploiteren. Ook de mogelijkheden in EG-verband tot aanbieden en ontvangen van zorg over de gremzen heen zijn in dit verband weinig hoopgevend.

Fragmentarisatie zal dus in de regel de mogelijkheden tot het opbouwen van een hulpverlener-patient relatie met respect voor autonomie beperken. Het gaat om ad hoc oplossingen woor momentaan gerezen knelpunten, die veeleer een langere termijn oplossing verdienen. 


\section{Protocollaire Geneeskunde}

De Nederiandse gezondheidszorg vertoont ten opzichte van de ons omringende landen een gunstig beeld ten aanzien wan de inspanningen om de kwaliteit van zorg toetsbaar te maken en te verbeteren. Er is een algemene instemming met het beleid om de zorg zo doelmatig mogelijk te laten verlopen en in het algemeen kan de Nederlandse gezondheidszorg als terughoudend bestempeld worden. Niet voor niets worden in Nederland in vergelijking met overige westerse landen nog steeds relatief weinig geneesmiddelen voorgeschreven. Ook wordt er veel geïnvesteerd in de ontwikkeling van richtlijnen en protocollen waarin die terughoudendheid veelal is terug te vinden. De beschikbaarheid van een algemeen geaccepteerde standaard voor adequate diagnostiek, behandeling en follow-up is wan grote waarde niet alleen voor de beroepsgroep maar ook voor patiënten. Tegelijkertija zijn er ook minstens twee kanttekeningen te plaatsen.

In de praktijk blijkt de omslag van de oude werkwijze naar werken volgens de richtlijn niet eenvoudig. Zoals met alle gedragsverandering kost het grote moeite or ingeslepen patronen te veranderen, standaard bepaald onderzoek te gaan doen, patiënten regelmatig voor controle terug te vragen, anticiperend te gaan werken. Het vereist aanpassing van de praktijkorganisatie en het verwerven van nieuwe vaardigheden voor een beleid dat deels op evidence, deels op consensus binnen of tussen beroepsgroepen gebaseerd is. Omdat richtlijnen doorgaans vooral appelleren aan effectiviteit van de behandeling/begeleiding voor het herstel van de lichamelijke functies, is er rellatief weinig ruimte voor de psychische en sociale component. Accentuering van de glycemische controle bij de diabetespatiënt laat relatief weinig ruimte voor een bredere aanpak waarin ook de psychische en sociale dimensie zijn verdisconteert.

Protocollen hebben al gauw de status de beste handelwijze te representeren bij de huidige wetenschappelijke kennis. De protocollaire richtlijnen worden daarmee verheven tot norm voor het handelen. Afgezien van het feit dat richtlijnen vaak de noodzakelijke wetenschappelijke 
basis ontberen, hebben zij ook weinig oog voor andere mogelijke keuzes dan die het protocol aangeeft. De richtlijin kan bij rigide toepassing op gespannen voet staan met het beginsel van autonomie. Immers zonder variatie en ruime tolerantiegrenzen rond de richtlijnen kan er geen sprake zijn van autonomie. Het is rekening houden met wat Ian McWhinney, een van de "founding fathers" van de Canadese Huisartsgeneeskunde noemde "The importance of being different". Protocollen zijn als het ware landkaarten die behulpzaam zijn bij het vinden van de medische weg. Maar het vinden van de weg naar een gebied is heel iets anders dan het gebied zelf kennen (24). Adequaat gebruik van richtlijnen veronderstelt derhalve flexibele toepassing die recht doet aan de verschillende behoeften en verlangens van verschillende patiënten in verschillende fasen van hun zielkte. Rigide toepassing en voorbij gaan aan de individuele verschillen tussen patiënten leidt meer dan eens tot "evidence based resistence", van expliciete weigering tot het latent verzet tegen het ingezette regiem van patiënten die zich onbegrepen voelen (7).

Rationalisatie van het medisch handelen middels protocollen verhoogt de efficiency. Dat is in een tijd van hoge werkdruk in de gezondheidszorg een groot goed. Tegelijkertijd dienen we ons te realiseren dat doelmatigheid op gespannen voet kan staan met het recht doen aan het autonomieprincipe.

\section{Selfmanagement als alternatief}

Tegen de achtergrond van de toenemende werkdruk en inzicht in het tekort schieten van de hulpverlening an chronisch zieken is de zelfmanagementbenadering als mogelijke oplossing geintroduceerd (vanuit de gezondheidszorg zelf maar ook vanuit patientverenigingen die steeds meer opkomen voor het patientenperspectief, waarvan een benadering die rekening houdt met de individuele verscheidenheid een van de peilers vormt\}. Het idee achter deze benadering is dat chronisch zieken zelf in staat zijn hun medische zorg te sturen. Daamaast ligt er voor henzelf buiten de spreekkamer een complexe taak bij 
het aanpassen van het rollenpatroon aan hun beperktere functioneringsmogelijkheden. Selfmanagement omvat dus de aansturing van de zorg voor de gezondheid, in al zijn facetten, door de patiènt zelf.

Aanvankelijk is zelfmanagement vooral een manier om patienten zelf meer bij de behandeling van hun ziekte te betrekken door ze een rol te geven bij het zelf monitoren van hun ziekte (bloedglucase rneten), zelf medicijnen te laten nemen (astma) en meer weloverwogen bezig te laten zijn met verandering van hun leefstijl. Een manier vooral om meer controle op het beloop van de ziekte te krijgen en dus mee te helpen aan verwezenlijking van de doelstelling van de arts. Het succes van zelfmanagementprogramma's wordt in eerste instantie dan ook vooral afgemeten aan het onder controle brengen van de ziekte, therapietrouw en vermindering van complicaties en ziekenhuisopnames en veel minder nog op het leren leven met een chronische ziekte.

Uit een mega-analyse (meer dan 400 publicaties) blijkt echter dat de meest succesvolle zelfmanagementprogramma"s het streven naar een gezamenlijk probleemdefinitie van hulpverlener en patiënt gemeen hebben (25). De onderzoekers formuleren de volgende kenmerken van succesvolle programma's:

1 Streven naar een gezamenlijke probleemdefinitie van patiënt en hulpverlener als uitgangspunt voor een zelfmanagement programma.

2 Het formuleren van een daarop gebaseerde doelstelling en planning om dat doel stapsgewijs te verwezenlijken.

3 Het aanbleden van zelfmanagementsupport in de vorm van trainingen en hulp bij de implementatie van het geleerde.

4 Actieve lange termijn follow-up

Met name de gemeenschappelijk onderschreven doelstelling vormt dus een wezenlijk element, omdat het tot uitdrukking brengt dat hulpverlener en patiënt gezamenlijk de ziekte trachten te managen. Ook anderen hebben dit 
als een wezenlijk element in de hulpverlening benadrukt $(26,27)$.

Tot dan toe hebben alle programma"s een ziekte-specifieke benadering, gericht op patiënten met diabetes mellitus, astma, artritis hartfalen of andere cardiovasculaire ziekten, ten teken dat het voomamelijk om initiatieven gaat die vanuit gespecialiseerde zorg werden opgezet, veelal buiten de reguliere zorg om. Baanbrekend werk is in dit verband recent gepubliceerd door een groep van de Stanford University te Palo Alto. Het idee achter de door hen voorgestane generieke benadering is dat leven met een chronische ziekte overeenkomstige consequenties heeft voor patiënten met verschillende chronische ziekten. In hun onderzoek werden patiënten geincludeerd met verschillende chronische ziekten, in verschillende fasen van het beloop, in de veronderstelling dat elke fase oprieuw om vergelijkbare adaptieve opgaven vraagt. In een grote interventie studie ( $N=952)$ wordt aangetoond dat dit zelfmanagement programma niet alleen tot aanzienlijke verbeteringen in de klassieke parameters als het onder controle brengen van de ziekte en kosten leidt, maar ook tot verbeteringen in beleefde gezondheid, validiteit en sociaal functioneren leidt (28).

De zelfmanagement benadering vormt daarmee een belangrijke aanvulling op de huidige gangbare zorg aan chronisch zieken. In deze benadering is het mogelijk recht te doen aan de autonomie van de chronisch zieke door de voorwaarden te creëren dat chronisch zieken zelf in overeenstemming met hun lichamelijke gezondheid in staat gesteld worden medisch verantwoorde eigen keuzes te maken bij de noodzakelijke aanpassingen in hun leefwereld. Blijkt een generieke benadering mogelijk, dan zal zelfmanagement ondersteuning heel goed door generalistische hulpverleners, bijwoorbeeld vanuit de thuiszorg, aangeboden kunnen worden. 


\section{Ten besluit}

Ik heb uiteengezet dat de hulpverlening zich in een lastige positie bevindt tussen respect voor de autonomie van de chronisch zieke en de professionele dominantie. Deze positie is des te lastiger in het huidige tijdsgewricht waarin de organisatie van de zorg door onderbezetting en toenemende werklast un zijn voegen kraakt. Ik heb voorbeelden genoemd van aanpassingen in de organisatie van de zorg, de ontwikkelingen op het gebied van de informatietechnologie en de protocollaire geneesikunde, die de doelmatigheid beogen te bevorderen, die alle, leder op een eigen manier de positie van de hulpverlener bemoeilijken. Factoren die de hulpverlening nog verder in zijn spagaatpositie kunnen drukken, zoals de ontwikkelingen van de medische techno-

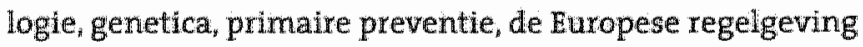
op het gebied van de gezondheidszorg, het wegvallen van mantelzorg en de toenemende heterogeniteit van onze samenleving bleven daarbij nog onbesproken. De betrokkenheid van de hulpverlener bij al deze ontwikkelingen zal concurreren met de vereiste zorg voor chronisch zieken.

Als de hulpverlening dus woorlopig in zo'n ongernakkelijke houding verkeert, moet de chronisch zieke zelf in actie komen. De chronisch zieke van de toekomst is zelfbewuster en beter geinformeerd over (de consequenties van) zijn chronische ziekte en zal beter in staat zijn voor zijn eigen belangen/behoeften op te komen. Zelfmanagement kan daarbij een belangrijke rol spelen. Het biedt de mogelijkheid de chronisch zieke een gevoel van meer grip op het leven met de beperkingen van de ziekte te geven.

In het medisch onderwijs worden studenten voorbereid op hun toekomstige taak in de gezondheidszorg. Op dit moment wordt in Maastricht het medisch curriculum her. zien. Het is geen toeval dat hierbij een betere en meer op de behoefte afgestemde verhouding tussen de aandacht voor acute en chronische ziekten wordt nagestreefd. De opleiding wordt daarbij in plaats van op ziekte meer gericht op de toekomstige arts en op de patiënt in diens sociale context. Denkend aan de vraag van de student uit mijn benoemingscommissie, hoop ik aan dit vernieuwde 
onderwijs een bijdrage te kunnen leveren door studenten in te wijden in de bestaande medisch-sociologische inzichten over de gevolgen van ziekte voor het dagelijks leven, de heel verschillende manieren waarop daarmee door patiênten en hun omgeving wordt omgegaan en de rol die hulpverleners daarin kunnen spelen. Hun aandeel in de ontwilkkeling van een zelfmanagement-attitude bij patiënten zal daarin prominent naar voren kunnen komen.

Wat betreft het onderzoek zal mijn focus vooral gericht zijn op de wetenschappelijke onderbouwing van de zorg aan chronisch zieken middels longitudinaal observationeel onderzoek naar de gevolgen van chronische ziekten voor deelname aan het sociale leven zoals gezin, werk en vrije tijd. Verder de wijze waarop patiënten met deze gevolgen omgaan als mede de sociale determinanten van de omgang met ziekte. Zelfmanagement neemt ook daarin een prominente plaats in. De medisch-sociologische benadering van de stress- en netwerktheorie gelden daarbij als uitgangspunt. Naast meer funderend onderzoek hoop ik interventiestudies te stimuleren naar het effect van selfmanagement ondersteuning op de functionele autonomie van chronisch zieken. Bij deze interventies zal zoveel mogelijk ook het gezin en de arbeidssituatie betrokken worden. De medisch-sociologische invalshoek bestaat hier vooral wit het gebruik van inzichten in relevante verschillen tussen sociale categorieën ten aanzien van de omgang met ziekte, met name bij het ontwerpen van interventies. Het spreekt vanzelf dat hiervoor ook leentje buur gespeeld zal worden bij de sociaall-psychologische theorieën over beinvloeding van gedrag. Samenwerking met medische disciplines lijkt mij bij de uitvoering van deze interventiestudies onontbeerlijk. Omdat hiermee een relatief nieuw onderzoeksveld wordt geëntameerd zal instrumentontwikkeling voor het meten van autonomie en zelfmanagement nodig zijn. Een glijdende start voor onderzoek op dit terrein is inmiddels binnen het kader van de instituten Health/Extra en de Capaciteitsgroep Zorgwetenschappen gemaakt. 
1. Pool A Autonomie, afhamkelijkheid en langdurige zorgwerlening [dissertatie], Rikswintwersitent Utrecht, 1995

2. Kuitert $H M$ Zelfododing, maral en hulpwerlering. In: Becufort ID de, Dupuis HM [red]. Haindboek Gezondheidsethiek; Van Goraun. Assen/Maastricht; 1988

3. Kuitert HM Autonomic: een lastige lautkomer in de ethiek [afscheldscollege] Vrije Universiteit, Amsterdam, 1989

4. Widdershoven GAM Autonomie in de hulpwerlening; Een herinterpretatie 1998 Tijdschrift waor de socialle sector; 1: 20-25

5. Widdershoven GAM. Ethiek in de kliniek. Hedendaagse benaderingen in de gezondheldsethiek. Boom: Amsterdam/Meppel, 2000

6. McWilliam $C_{\text {, B }}$ Brown $J B$, Carmichael $L$, Lehman IN. A new perspective on threatened autonomy: the disempowering process. Soc Sci Med 1994: $38(2): 327 \cdot 38$

7. Haymes RB, McKibbon KA, Kamani $R$. Systematic review of randamised trials to assilst patients to follow prescriptions for medications. Lancet $1996 ; 348: 383-386$

8. Perenboom RUM, Herten LM van, Boshuizen HC en Water HPA wan de. Trends in de gezonde levenswerwachting in Nederland 1983-2994, met een werdeling naar de ernst wan ongezondheid. In: Maas PIM van der, Kramers PGN. Volksgezond heid; Toekomstverkenning 1997, deel III Gezondheid en lewenswerwachting gewogen; Elsevier/ De tijdstroom. 1997

9. Wijst Twan der, Zwiers R. Zorgen over de zorg vam morgen Demas 1999: 15,7376

10. Bergh Jeths wan den $A_{\text {, Ruward }} D_{*}$ Verkley $H$. De invloed van demografische en epidemiologische antwikkelingen op het antal chronisch zieken in de toekomst. TSG 2000; 78: 75-80.

11. Wagner EH, Austin BT, Konff M won. Organizing care for patients.(1996) The Milbank Quarterly; $74511-544$ 


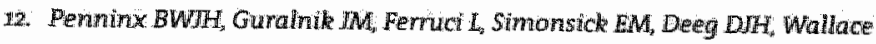
RE. Depressive symptoms and physical dechine in community dwelthy older persons. IAMA 1998; 279: 1720-1726

13. Penninx BWIH, Geerlings S, Deeg DIH, Eijk JThM van, Tilburg W" wan, Beekman ATF. The effect of minor and major depression on the risk of death in old age. Arch Gen Psychiatry 1999: 56:889-895

14. Penminx BWIH, Beekman ATF, Honig A, Deeg, DIH, Schoevers RA Eijk I TH M van, Tilburg W van. Depression and Cardiac Mortality. Results from a Community-based longitudinal study Arch Gen Psychiatry (conditionally accepted)

15. Watkins LL, Grossman P. Association of depressive symptoms with reduced baroreflex cardiac control in coranary artery disease. Am Heart 1999:37:453-457

16. Camey RM, Saunders RD, Freedland KE, stein P, Rich MW, Jaffe S. Association of depression with reduced heart rate wariability in coronary artery disease. Am 3 Cardiol $1995 ; 67: 562-564$

17. Gullette ECD, Bumenthal JA, Babyak Ma Wagh RA, Frid DJ Oçonnor $C M$, Motris J, Krantz DS. Effects of mental stress on myocardial ischemia during daily life. JAMA 1997; 277:15:21-1526

18. Camey RM, Freedland KE, Rich MW, Jaffe AS. Depression as a risk foctor for cardiac events: a review of possible mechanisms. Ann Behaw Med $1995: 17: 412-149$

19. Szasz T, Hollender M. A contribution to the philosophy of medicine: The basic models of the doctor-patient relationship. IAMA 1956, 97:585-8

20. Rolland IS. Chronic illness and the lifecycle: a conceptual framework. Family Proc 1987; 26:203-21

21. Ejh JThM wan Care for the chronically ill the future role of health carse professionals and their patients 1998. Pat Educ Couns 35:233-4013.

22. Litzelman DK, DitusME, Miller ME, Thierney WM Reguiring Physicians to respond to computerized treminders improves their compliance with preventive care protocols I of Int Med 1993; $8: 311-17$ 
23: Spreeuwenberg C Netwerken van chromisch zieken foratiel Waostricht, 1995

24. McWhininey IR. The importance of being different, $B$ IGP 1996, 46:433-436

25. Center for Adwantement of Health 1966 . Indexed Biblography of behavioral Interventions of Chronic Disease. Washington, D.C.

26. Korff M won, Gruman $I_{1}$ schaefer 1 , Cury SJ, Wagner Ed. Coilaborative Management of chronic illness. Ann Intern Med. 1997: 127: 1097-1102

27. Charles $\mathrm{C}$; Gafni $A$, Whelan T. Decisionmaking in the physician-patient encounter: revisiting the shared treatment decition making model soc Sci Med 1999:49:651-61

28. Lorig K, Sobel DS, Stewart AL, Brown BW, Bandura A, Ritter P, Gonzalez, $V M$, Laurent $D D$. Holman $H R$. Evidence suggesiting that a chronic disease self-management program cam improve health status while reducing hospitalization. Medical Care 1999: $1: 44$ 


\section{" De WAO, de thuiszorg en de} Bijlmerramp: randgebieden rond het medisch centrum van de gezondheidszorg"

H. Philipsen

Afscheidsrede

In verkorte vorm uitgesproken bij zijn afscheid.

30 juni 2000 
28 


\section{" De WAO, de thuiszorg en de}

\section{Bijlmerramp: randgebieden rond het medisch centrum van de gezondheidszorg"}

\section{Op zoek naar Zorgland}

Vandaag staan wij aan de vooravond van de zomervakantie. Velen van u zullen afreizen naar andere streken. In de keuze van uw vakantiebestemming weerspiegelt wich ongetwijfeld niet alleen een voorkeur voor zon, zee en vertier, maar ook voor de wijze waarop men elders de zaken geregeld heeft. Die voorkeuren kunnen sterk verschillen. Ik beri er niet wars van mijn tijd door te brengen in een omgeving die wel anders maar ongeveer even ordelijk en aangeharkt is als thuis. Stuur mij maar naar Zwitserland, Denemarken of Engeland. Meer avontuurlijke aangelegde lieden deinzen niet terug voor trektochten in landen war het bestaan van een hoofdstad en een vliegveld weliswar de illusie scheppen van eenheid en overzicht, maar vijftig kilometer verder weet men wel beter. Darr gat het anders toe dan men ooit had kunnen verwachten. In leder geval kan men de gedachte laten varen dat zelfs all zou men een regeringsambtenar tegenkomen, deze in stat en bereid zou zijn, veel voor u te doen. Kortorn, a als avonturier heeft gekozen voor een uitdaging. Laat ik het daar naar bij laten. 
Varrmiddag vraag ik u gezondheid, ziektte en gezondheidszorg alls een denkbeeldig land te beschouwen. De samenleving valt op allerlei wijzen in sectoren uiteen, zoals onderwijs, het bedrijfsleven, sociale voorzieningen, de openbare orde, natuur en milieu, kunst en cultuur en ook de gezond heidszorg. Het is met deze sectoren net als met landen gesteld.

Ze verschillen in de mate:

- waarin er sprake is van een duidelijk centrum;

- waarin centra invloed hebben op de buitengewesten;

- waarin er duidelijke grenzen bestaan en er geen overlap is met andere sectoren;

- waarin partijen die verschillende belangen en doeleinden nastreven, tegenover elkaar staan en in de wijze

- waarop de verhoudingen tussen de organisaties, de beroepen, het publiek en de overheid zijn geregeld.

In wat volgt verzorg ik een korte rondreis in Zorgland. Het is in belangrijke mate een historisch reisje waarin $1 k$, wat u ziet in het jaar 2000, confronteer met de ontwikkelingen in de sector in de loop van mijn leven. Wie een landschap beschrijft, moet het waargenomene reduceren tot fragmenten die vanuit één of meer gezichtspunten vallen te begrijpen en te ordenen. $\mathrm{Lk}$ werk vanuit twee perspectieven:

- Het eerste betreft de noodzaak voor elke wetenschapsbeoefenaar om weet te hebben van de primaire processen die hij of zij( in het vervolg alleen hij) bestudeert. Wie een uitspraak doet over Zorgland, moet kunnen aantonen dat wat hij beweert spoort met wat er gebeurt als mensen met klachten naar de dokter gaan, als de wijkverpleegkundige ergens aanbelt om een chronische zieke te verzorgen, als iemand zich ziek meldt orndat hij zich niet lekker voelt, als een verstandelijk gehandicapte in het busje stapt naar de dagopvang en zelfs als Jomanda uw krat mineraalwater instraalt. In de wetenschap kan men niet zonder variabelen, getallen en tabellen. Men moet echter wel blijven kijken naar de gewone of ongewone werkelijkheid.

- Mijn tweede perspectief betreft de theoriekeuze.

Ik behoor tot de sociologen voor wie het begrip 
institutionalisering het centrale begrip van het vak is. Dat wil zeggen dat het menselijk gedrag zowel genormeerd als normatief is. Gewormeerd ondat het patronen vertoont die gemakkelijk zijn vast te stellen, maar die het individu vaak niet kent en ook niet $k a n$ beinvloeden. Normatief is ons gedrag omdat zich al doende regels en 'afspraken' ontwikkelen die zich al of niet tijdelijk tot een institutie werdichten. Bestudering van deze instituties op het niveau wan de samenleving is de pretentie van de macrosociologie.

Hoewel ik fysiek nooit tot de spagaat in staat ben gewrest, probeer ik het wetenschappelijk al heel lang. Mijn ene been reikt naar, om het mooi te zeggen naar de fenomenologie van ziekte, gezondheid en gezondheidszorg, het andere probeent terecht te komen waar abstracte begrippen als centrum, periferie professie, moderniteit, rationaliteit, techniek, doeleinden en hulpmiddelen in dymamische verbanden worden samengebracht. Als u van etiketteren houdt: ik voel mijzelf een numeriek geschoold symbolisch interactionistisch neo-institutionalist.

\section{Het landschap in: vier ontmoetingen}

In 1938 werd de huisarts Ruhe op een zondagmorgen in mei in Hilvarenbeek ontboden bij een bejaarde boer. Het was de eerste keer dat in het gezin een dokter werd geroepen. De man toonde de arts een geweldig gezwollen scrotum dat tot onder de knieën reikte. Na vele jaren gedacht te hebben dat het wel weg zou gaan, was hij deze morgen ongerust geworden, omdat hij zijn zondagse broek niet meer aan kreeg. Hij kon daardoor nift meer naar de kerk. Naar het ziekenhuis wilde hij niet; de dokter bevrijdde hem van de grootste last door vijftien liter helder vocht af te tappen. Hoewel van genezing geen sprake was, ging de broek weer an en werd de kerk weer bezocht.

In 1954 beschrijft dezelfde hwisarts een typische casus wan na de tweede wereldoorlog. Een mevrouw van 51 is al vijf jaar onder behandeling voor hoge bloeddruk. Ze heeft in een kamp gezeten. Toen ze na de oorlog met haar kinderen terugkwam bleek haar man met haar gebroken te hebben. ze heeft ooit een apoplexie gehad en een gestoorde 
nierfunctie. De chronisch resterende klachten variëren vooral met de ups en downs van haar persoonlij $k$ leven. Aarpak met diëten en bloeddrukverlagende middelen heeft een negatieve witwerking.

Tot zover Ruhe die in 1957 promoveerde en die in beide beschrijvingen een scherp oog voor strategische voorbeelden blifjkt te bezitten. Voor de rest van de vorige eeuw gebruik ik eigen walarnemingen. 1k kies daarbij net als Ruhe voor voorbeelden waarbij niet zozeer de sterfelijkheid aan de orde is, maar de meer alledalagse kwetsbaarheid door ziekte. De afgelopen periode hebben verschillende media mij een aantal al of niet vermeende geheimen uit mijn leven ontfutseld. Eên hebben ze niet ontdekt; ik vind dat ik er eens eerlijk vooruit moet komen. Het is nu Rondom Vijf, dus tijd voor een intieme bekentenis voor een zaal met goed en begrijpend publiek. Mijnheer de Rector, dames en heren, ik heb last van aambeien. Eigenlijk is dat niet het goede woord; ik heb een kwaal die erop lijkt en ongeveer hetzelfde ongemak oplevert. En mijn ongemak kent ups en downs. Soms gaat het zo down dat een ingreep wenselijk wordt geacht. In 1966 verwees mijn huisarts mij naar een chirurg die nog polikliniek hield in de verschillende randgemeenten van Den Haag. Na een summier onderzoek en zeer korte uitleg over wat me te wachten stond moest ik wachten op opname. Ik kwam terecht in een kleine kliniek waar deze chirurg op zaterdagmorgen kleine operaties op particuliere patiënten uitvoerde. Volledige anesthesie was mijn deel. Gedurende vijf volledige dagen werd mijn spijsvertering stilgelegd, opdat op de zevende opnamedag het wonder van de eerste ontlasting weer zou kunnen plaatsvinden. Aangezien die activiteit zonder verdoving geschiedde was de status van de patiént bij de verpleegkundigen afhankelijk van de vraag of men wel of niet flauw zou vallen. Bijna alle verpleegsters waren van de Filippijnen afkomstig. Ir is dus niets nieuws onder de zon. De verpleging was zorgzaam maar ook gestandaardiseerd. De chirurg heb ik drie keer aan mijn bed gezien en éen keer op controle. Na elf dagen mocht ik naar huis. Na vier weken ging ik weer aan het werk De behandeling was zo ingrijpend dat de duur van de arbeids ongeschiktheid niet ter discussie stond. Over de kwaal zelf 
en hoe die thuis te verzorgen of te voorkomen, heb ik nooit iets anders vernomen dan de noodzaak wan hygiene.

In 1996 was het weer zover. Na enige diagnostische omzwervingen kwam ik terecht bij een gespecialiseerd huidarts; een proctoloog, de eerste persoon die meer van de ormgang met mijn kwaal afwist dan ik zelf. $\mathrm{Na}$ ampele overwegingen kwam hij tot de conclusie dat een poliklinische ingreep onder plaatselijke verdoving op zijn plaats was. Deze ingreep deed mij hooguit twee tot drie uur in het ziekenhuis belanden. Bij de ingreep werd hij geassisteerd door één verpleegkundige. Toen ik weg mocht, vroeg ik aan de dokter wanneer ilk weer kon gaan werken. Ach zei hij daar valt zo weinig over te zeggen. Sommige mensen hebben er een paar dagen last van, maar ik heb lemand gekend die voetbalde s' middags weer. Op de gang kwam de verpleegkundige ons achterop. Meneer, zei ze, als ik u was kunt $u$ beter tot maandag thuis blijven. En als u een bloeding krijgt, dat zou best kunnen, komt u dan onmiddellijk naar ons terug. Het meest opmerkelijke aan de moderne vorm van specialisatie is dat de arts niet alleen gericht is op de ingreep maar ook verstand heeft van deze betrekkelijk gewone aandoening en in hoeverre je die kunt beheersen. Jaarlijkse bezoeken aan het medisch centrum bevorderen dat ook. Deze combinatie van openheid en toegenomen kennis heeft ook enkele nadelen. Toen ik de eerste keer op controle kwam, deelde hij me het goede nieuws mee: het was niet kwaadaardig. Sinds die dag is de onschuld die ik mijn ongemak altijd toedacht, afgenomen.

In 1938 is het ongemalk, niet de aandoening de beslissende factor in de hulpvraag. Het geheel speelt zich in de periferie af. In 2000 zou dat ondenkbaar zijn. In 1954 bestaari er klachten waarvan de relatie tot een eventuele aandoening betwijfeld wordt. Het is een eerste teken van het afnemend belang van klachten. Het is daarbij niet toevallig dat een vrouw als voorbeeld wordt genomen. In 1966 is het gewoon geworden dat men ook met zijn vervelende maar niet levensbedreigende kwalen vanuit de periferie naar het ziekenhuis in de stad gaat. Daar wordt men stevig aangepakt, een tijdje ingesloten, alvorens men 
weer tot de orde van de dag overgaat. Over de behandeling bestaat zekerheid, over het verloop van de aandoening. wordt niet gerept.

In 1996 komt men snel in het academisch medisch centrum terecht; waarin het medisch specialisme van aard veranderd blijkt te zijn. De arts is transmuraal geworden; hij kijkt met de patiènt mee in de keuken en de badkamer. Hij wil het medisch wel zuiver houden. Over afhankelijkheid en arbeidsongeschiktheid gaat hij niet. Gelukkig bleek de verpleegkundige nog niet geheel uit het medisch centrum verbannen.

\section{Vier betekenissen van ziekte in het medisch centrum}

Mijn voorbeelden hebben één kermerk gemeen. In alle gevallen is er sprake van een aandoening, van bijbehorende klachten en lijden, van ongemak en afhankelijkheid en van het zoeken van hulp. Er bestaat een zekere eenheid van deze elerrienter; ze zijn vier aspecten van wat men ziekte zou kunnen noemen.

1 Ziekte als aandoening duidt op een diagnostisch proces, waarbij men door lichamelijk anderzoek, meestal ondersteund door biomedische bepalingen, tot een uitspraak komt over een objectieve biologische of psycho-organische stoornis: disease.

2 Zlekte als lijden, het hebben van klachten en pijn: illness.

3 Ziekte als afhankelijkheid en ongemak. Men kan niet langer functioneren zoals men zou willen. Men kan zijn rollen en plichten niet vervullen zoals voorheen: sickness.

4 Ziekte als het zoeken van hulp. Het zich al of niet ondergeschikt maken aan professionele oordelen en aan therapeutisch of verzorgend handelen is een onderdeel van het ziekteproces.

In deze visie op ziekte worden aandoening, lijden. ongemak en zorg wel onderscheiden, maar vallen ze niet te scheiden. Men kan daar anders over denken. Juist in de periode van mijn leven is er tenminste een andere visie op ziekte ontstaan, die voor- en tegenstanders kent. Een enkel 
citaat dat ik aantrof in het recente proefschrift van Ineke Widdershoven volstaat. In vertaling luidt het: " Klachten en pijn worden terzijde geschoven als de wetenschappelijk getrainde dokter op het authentieke maar verborgen spoor kornt van ziekte als biologische pathologie. De ziekte als een objectief natuurlijk gegeven raakt gescheiden van de ervaring van het lijden waarmee het eens nauw verbonden was".

De ziekte wordt hier gelijk gesteld aan de aandoening. Sinds de biomedische en technische triomfen van de geneeskunde, zou het aantonen van objectieve aandoeningen de subjectieve klachten uitbannen. Het valt niet te ontkennen dat veel mensen deze mening delen en dat ook de spraakmakende medische gemeenschap in ongeveer de periode 1960-1990 dicht in de buurt van dit standpunt kwam. Een empirische analyse van Zorgland leidt tot de conclusie dat het hier om een typische halve waarheid gaat. De ontwikkelingen hebben er inderdaad toe geleid dat in het centrum van de zorg de aandoening als aspect van de ziekte dominant is geworden. Tot in de eerste helft van de vorige eeuw waren klachten en ongemakken gemakkelijker vast te stellen dan aandoeningen en vormden deze vaak het aangrijpingspunt van het medisch handelen: Deze toestand is sterk veranderd. In de specialistische geneeskunde is het thans betrekkelijk eenvoudig om vast te stellen of jemand 'echt' iets mankeert. Bovendien kan dit door de technische vooruitgang vaak leiden tot een specifieke therapie op grond van een specifieke diagnose. Hieruit volgt nog niet dat klachten er niet toe doen. Alleen zijn aandoeningen de noodzakelijke voorwaarde geworden om van ziekte te spreken. Klachten worden nog steeds behandeld. Arbeidsongeschiktheid en ongemak zijn toegestaan, zolang er een aandoening is vastgesteld. Mensen met veel klachten bij wie "niets" of "niet echt' lets wordt aangetoond zijn er daardoor nauwelijks beter aan toe dan wanneer de ziekte als echt wordt erkend. Er bestaat thans een succesvolle geneeskunde die veel, maar lang niet alles kan en die zich in het centrum van zorgland heeft gevestigd. Ziekenhuizen, ooit gasthuizen zijn medische centra geworden die georganiseerd zijn rond de aanpak van aandoeningen. zij vervullen ook voor het gehele zorgland een centrumfunctie. Centrum 
en periferie vormen een geheel. Er bestaan afspraken en protocollen hoe gezondheidsproblemen aan te pakken, over diagnostiek en therapie, over door -en terugverwijzing. De geneeskundige zorg is hard op weg transmuraal te worden en aain allerlei nieuwe vormen van samenwerking en protocollering vorm te geven. Deze doorbraak naar ontwikkeling en centralisering van kennis ontrent aandoemingen in het medisch centrum, gekoppeld aan een geleide decentralisering en verspreiding daarvan naar de periferie, berust niet of niet alleen op een onvermijdelijke triomf van een medisch technisch complex. Tenminste twee andere nauw verbonden tendenties zij̄n van belang.

De eerste is het streven naar medische zuiverheid. De modeme arts streeft naar het effectief en volgens de laatste stand van de wetenschap vaststellen van aandoeningen. In die visie verdwijnen klachten en ongemak niet, maar zij hebben een ander belang gekregen. Het zijn in de praktijken bedrijfsvoering van het medisch centrum bijzaken geworden, niet onbelangrijk, maar niet geheel ter zake. In het ziekenhuis kun je medisch uitbehandeld raken en in het verkeerde bed terechtkomen. De verblijfsfunctie bij blijvende of langdurige afhankelijkheid van de patiënt wordt uit het centrum van de gezondheidszorg, naar meer perifere verpleeghuizen, gespecialiseerde klinieken, voorzieningen voor terminale zorg of gewoon naar huis verlegd. Evenzo kunnen lijden, klachten en pijn zijn uitbehandeld met doorverwijzing naar voorzieningen in de geestelijke gezondheidszorg, naar gespecialiseerde voorzieningen als pijnklinieken, naar een baaierd van al of niet alternatieve trainingen en therapieën of ook in dit geval naar huis. De medische zuiverheid heeft het ongemak en het lijden niet afgeschaft. Zij blijven erkend, maar zijn gedecentraliseerd.

De tweede tendentie is de opkomst van de zogenaamde evidence based medicine. Daarin handelt de arts op grond van wetenschappelijke gefundeerde kennis. Als onderzoek heeft aangetoond dat bij een specifieke diagnose een specifieke therapie bewezen effect sorteert, is er reden tot handelen. Bovendien ontstaat door de acceptatie van dit gezichtspunt meer kennis orntrent ziektes en beloop van aandoeningen. Door deze combinatie van gerichtheid op de 
aandoening, medische zurverherid en evidence based medicine lijkt een moderne professional te ontstaan die niet langer voldoet aan het stereotype van de slecht stuurbare superspecialist. Hij is meer een deskundige op het gebied van disease management die aan wetenschappelijke onderzoek doet en weet dat hij het niet in zijin eentje kan. Wanneer wij nu de blik op Zorgland richten, dan lijkt het voorzover het om aandoeningen gaat op een soort Zwitserland, Nederland of Denemarken. Het gaat er modern en redelijk aan toe. Een aangeharkt larud met goede verbindingen, met duidelijke centrumfuncties en een prima bewegwijzering. Helaas is er zo nu en dan filevorming, enig wangedrag in het verkeer en constant ruzie over tolwegen en snelheidstreinen. Zoals ik all zel: ik ga graag naar zo"n land met vakantie. De reiziger weet echter ook dat je zelfs in Zwitserland sommige streken en buurten beter kunt mijden en dat niet alle $Z$ witsers even gelijk of goed af zijn.

Bovendien zien sommige $Z$ witsers een deel van de inwoners liever gaan dan komen. Het wordt tijd dat ik u een kijkje gun in de periferie van Zorgland.

\section{Arbeidsongeschiktheid het buitengewest dat de hoofdstad wel kwijt wil}

Indien Zorgland bestond, zou er ongetwijfeld een negatief reisadvies gegeven worden voor de roerige WAOstreek. De pax medica staat daar onder grote druk. Wat is er aan de hand? Sinds ruwrweg 1955 vindt men in Nederland het ziekteverzuim hoog. Tot in 1967 de Wet Arbeidsongeschiktheid werd ingevoerd bestempelde men de toestand hooguit als zorgelijk. Nadien gaat het van kwalad tot erger. Er zijn parlementaire enquëtes gehouden; alle bestalande regelingen zijn voortdurend onderwerp van reorganisatie. Iedereen geeft jedereen de schuld. De werknemers zouden zich lichtvaardig ziek melden. De werkgevers zouden hun oudere werknemers dumpen in de WAO, en de ARBO-wetten niet uitvoeren. De politiek weet niet van aanpakken. En vooral de uitvoeringsinstanties, in het bijzonder de verzekeringsartsen, zouden hun werk niet naar behoren doen. Zoals bekend komt men met blaamwerpende diagnoses niet ver. Laat ik teruggaan tot de kem van de zaak. Een werknemer 
meldt zich ziek orndat hil we extra moeite die het kost met bepaalde klachten en ongemakken aan het werk te gaam, niet meer kan of wil opbrengen. Deze werknemer bijft cen zekere tijd weg; tot hij al of niet in overleg met deskundigen, zich voldoende hersteld acht. De viaag of de ziekmelding en of de ziekteduur gerechtvaardigd zijn, ugt feitelijk op het bureau van de verzekeringsarts. Het lijkt mij nu de gelegenheid klare taal te spreker. De arts doet zijn best en levert wolgens onderzoek veel beter werk af dan in de krant staat, maar hil is tot op zekere hoogte getraind incompetent or zón oordeel te geven. Wie in zijn opleiding leert de medische zuiverheid te betrachten, en zich verre te houden van ongefundeerde uitspraken over klachten; ongemak en athanke$113 k$ heid, start het yerzekeringsgeneeskundig handwerk met twee linkerhanden. Van hem of haar worden uitspraken verwacht die niet op evidence based medicine berusten, maar die naar eer en geweten als de minst slechte conclusies kunnen worden beschouwd. Daarbij komt dat het oordeel over arbeidsongeschiktheid, in bijna alle gevallen, of het nu om griep gaat of om kanker, intersubjectief van aard is. Wij mensen hebben met ons allen op een diffuse wijze afspraken gernaakt over wat als ziekmelding en ziekteduur acceptabel en behoorlijk is. De ziekmelding is een typisch voorbeeld van een institutie. Het betreft echter een instabiele institutie. Oorspronkelijk meldde men zich alleen ziek met 'echte ziekte' waardoor het werken onmogelijk was. Ook de ziekmelding wegens griep of verwante kwalen is vanaf het begin van de ziektewet acceptabel. Het zich op grote schaal ziek melden met lichtere maag- en darmkwalen doet zich pas woor na 1945. In de jaren zestig wordt het normaal met rugpijn te verzuimen, terwijl pas daarna de lichtere psychische stoornis op de voorgrond treedt, als reden voor afwezigheid: Men kan dat moeilijk de verzekeringgeneeskunde kwalijk nemen. Men geeft tenslotte ook het KNMI niet de schuld van wind, regen of zonneschijn.

De beoordeling van afwezigheid wegens ziekte wordt bovendien nog bernoeilijkt door ontwikkelingen in de zorg. Veel ingrepen geschieden anno 2000 zo effectief en efficiënt dat zij een veel geringere verzuimnoodzaak opleveren. $1 \mathrm{k}$ herinmer $u$ aan mijn lotgevallen in 1966 en 1996. Bovendien is 
eer onverwachte uitkomst van de opmars wan evidence based medicine dat het voorschijven van rust, laat staan bedrust, als therapie in de geneeskunde weinig meer voorkomt. Daardoor is aan de verzekeringsarts een laatste quasi-objectieve maatstaf voor zijn oordeel ontvallen. Aan de werknenter, de huisvroww en de scholier ss een mogelijheid ontnomen om erkend afstand te nemen wan de dagelijkse druk.

Het is duideligk Zorgland die de WAO-streek samen regeert met het bururland Sociale Zaken en Werkgelegenheid heeft aan zing grenzen een probleem. In het begin van de jaren negentig heeft Rienk Prins vastgesteld door goed ontworpen eigen onderzoek dat men zich in Nederland inderdaad vaker ziek meldt dan in de nabuurlanden en bovendien. langer wegblijft. Recent heeft hil samen met andere onderzoekers van zịn instituut een grote vergelijkende studie gepubliceerd van langdurige arbeitsongeschiktheid wegens lage rugpijn in zes landen. Daanut blifkt dat Nederland in de behandeling van WAO-ers het verhoudingsgewijs goed doet.

De politiek en het bedrijfsleven zouden wat dit betreft best wat minder kippendrift mogen tonen. De conclusie die wel getrokken moet worden is onthutsend simpel. Nederland heeft meer WAO-ers omdat er meer ziekmeldingen zijn. Dat hoeft niet erg te zijn als het een soort algemeen verschijnsel zou zijn, bijv. een Nederlandse variant op hoe de prepensionering te regelen. Dat is echter niet het geval. Nu grote groepen betrekkelink jonge mensen, vooral yrouwen met klachten van het bewegingsapparaat en psyclusche stoomissen, al of niet in het modeme gewaad van burnout, in de WAO komen, is ex fundamenteel lets mis.

\section{Waarom heeft Nedexland meer aiekmeldingen?}

Er bestaat een neiging om het verschijnsel cultureel te verklaren. Kort gezegd, Nederlanders zijn individualisten en streven ook consensus nat Als je door ziekte ongemak krijgt, het op het werk niet goed gaat, hebben de Nederlanders een stilzwijgende afspraak met elkar gemaakt: liever ziek thuis dan in de weg loper of collectief ruzie maken. Verrolgens raken we zo vertrouwd met het Poldermodel, dat het als een cultureel software programma tussen de oren komt te aitten. Prachtig beschreven en niet onwaar. Als neo-institutionalist 
moet ik echter waarschuwen tegen puur culturele verklarimgen. $\mathrm{k}$ virud dat ze pas aan de orde komen als structurele verklaringen volledig falen. En dat is niet het geval. Ex zijn namelijk enkele simpele verschillen tussen Nederland en het meeste buitenland.

- In Nederland hoeft men de ziekmelding pas achteraf te rechtvaardigen. Daarvoor heeft men gewoonlijk geen medisch attest nodig.

- In Nederland bestaat al heel lang zowel een strikte scheiding tussen behandeling en controle als strikte regels over wat behandelend artsen meedelen aan verzekeringsgeneeskundigen.

Wanneer wij daaralan de stelling toevoegen dat in het centrum van de zorg de geneeskunde zich niet langer uitlaat over ongemak en afhankelijkheid bij arbeidsongeschiktheid, dan is de wanorde in WAO-land begrijpelijk. Het is niemand zijn schuld, maar het is wel dweilen met de kraan open. Men

$40 \quad$ kan de oplossing van het probleem op een simpele wijze bevorderen.

- Maak de ziekmelding moellijker door grotere sociale beheersing of door een negatieve prikkel. In 1972 heb ik de Sociale Verzekeringsraad voorgesteld om elke eerste ziektedag als vrije dag af te boeken. Daarvan is nooit iets gekomen. Nu de Nederlanders anno 2000 hun verlofdagen nauwelijks opgenomen krijgen, lijkt deze ingreep voor de hand te liggen. Fen dergelijke maatregel schept bovendien voor de werknemers de mogelijkheid voor goede arbeidsomstandigheden op te komen bij de werkgevers.

- Hef de strikte scheiding tussen behandeling en controle op. Het is gelet op de lange geschiedenis geen simpele zaak. Het zou de geneeskunde echter geen kwaad doen als zij ondanks hun streven naar medische zuiverheid op het gebied van het oordeel over arbeid en ongemak, het maatschappelijke belang daarwan beter zouden inzien. Juist in het centrum vari de zorg heeft men baat bij een kleinere instroom in de WAO van jongere mensen wier klachten men niet goed kan plaatsen. Zij zjjn immers ook in grote getale in behandeling. 
Minn conclusie is helder. De WAO-streek moet onder het gezag van Zorgland blijven.

5 Volksgezondheid: de vergeten provincie waarwan men in de hoofdstad niet eens de grenzen kent

Tijdens de parlementaire enquete over de Bijlmerramp werd het de Minister van Volksgezondheid knap lastig gemaakt. Daarbij heeft zij herhalide malen verklaard, dat een algemeen wetenschappelijk onderzoek naar de gevolgen van de Bijlmerramp niet gehouden kon worden. Bij onderzoek moet men weten wat men wil meten. Indien er geen aanleiding is te vermoeden dat een specifieke oorzaak een specifiek gevolg heeft, zou de wetenschap buiten spel staan. Zij kon zich wel voorstellen dat mensen klachten hebben. Dat was echter onvoldoende reden toe te geven aan de wens van nader onderzoek, dat 'niets' kan opleveren. Hoewel ook op methodologische gronden op deze stellingname veel valt af te dingen, zal ik dat niet doen. Het zou een afzonderlijk verhaal vragen. Er blifft echter voldoende aanleiding over om zich te verbazen over de minister en haar hooggeleerde adviseurs. Om te beginnen is het standpunt een duidelijk voorbeeld van de medisch zuiverheid. Gezondheidsklachten moeten wel serieus genomen worden. Ze verdwijnen echter wit het zicht zodra de epidemiologische criteria voor evidence based medicine niet van toepassing zijn. Hierbij komt men dicht bij een exclusieve opvatting over ziekte als een aandoening met bij voorkeur één enkele biomedische oorzaak. Men wordt dan roomser dan de paus. Iust van veel levensbedreigende en/of degeneratieve ziekten wordt vooralsnog aangenomen dat zij multicondi“ tioneel verklaard moeten worden. Men behandelt de ziekte, ook al kent men de oorzaken niet. Daarnaast wordt wetenschappelijk onderzoek gedaan om meer over oorzaken en gevolgen te weten te komen. Er zijn weinig argumenten om bij serieuze gezondheidsklachten na bijvoorbeeld een ramp van een vergelijkbare werkwijze af te zlen. Natuurlijk wordt de discussie over een dergelijk onderzoek ongunstig bein vloed door beduchtheid voor budgettaire consequenties aan de kant van de autoriteiten en door angst voor geheimzin nige effecten aan de kant van de slachtoffers. De enige 
verstandige reactie is het geyraagde onderzoek wel te doen. Bij elk denkbaar onderwerp in de Nederlandse politiek is dat de standaardpraktijk. Het lijkt er op of men ellke kans dat er wel degelijk een verband tussen ramp en ziekte bestaat, wil uitsluiten. Men kiest voor liever geen uitkomst dan voor de kans op een fout positieve. Overigens ziet het er naar uit dat men in Enschede de zaak verstandiger aanpakt. Daarbij neemit men terecht genoegen met een minder harde" methodiek van het onderzoek.

Wellicht een punt van groter principieel belang in de opstelling vormt het begrip gezondheid dat gehanteerd wordt Kennelijk worden ziekte en gezondheid als uiteinden van een continuüm gezien. Wie niet ziek is, is gezond. Ben je gezond, dan ben je niet ziek. In 1997 is door de Wetenschappelijke Raad voor het Regeringsbeleid een rapport onder de titel Volksgezondheidszorg uitgebracht. Daarin staat op de pagina's 128 en 129 duidelijk uiteengezet dat het volks-

42. gezondheidsbeleid een beperkte definitie van gezondheid moet kiezen: afwezigheid van ziekten en andere gezondheidsproblemen zowel van lichamelijke als psychische aard. De raad geeft voorbeelden van wat geen gezondheidszorg is. Ik noem onder andere een cursus van het RIAGG voor weduwen, een anti-pesten campagne op school, anticonceptiemiddelen, psychotherapie na echtscheiding en kuuroorden woor reumapatiënten.

Als ik mijn gemoed zou mogen laten spreken, welt als eerste reactie het woord 'kinderachtig' in mij op. Ook zonder bezwaard gemoed, blifft er voldoende ruimte voor commentaar. De kracht van het oude volksgezondheidbeleid was onder andere dat het zich tot taak rekende bij te dragen aan het kinderen veilig groot te brengen en volwassenen beschermen tegen de kwetsbaarheid wan het bestaan. Al de door mij gekozen voorbeelden hebben daar mee te maken. $\mathbb{l k}$ kan mij niet voorstellen dat iemand zou vinden dat deze voorzieningen moeten worden afgeschaft. Men zou waarachtig gaan denken dat het puur om de kosten gaat. In dat geval maakt de Raad een denkfout. Zorgland is een segment van de samenleving, niet een departement van de overheid. Zorgland heeft, wat men er in de hoofdstad ook van vindt, 
een provincie Volksgezondheid. Natuurlikk kan men er minder geld en mensen naar toe sturen. op temijn levert dat ernstige problemen op. Een wil ik er noemen omdat het de al genoemde denkfout verergert. Gezondheld en ziekte liggen niet op een continuüm. Men kan niet bij wetenschappelijk decreet de menselijke ervaring van zich gezond voelen afschaffen. $U$ weet net zo goed als ik dat men niet gezond en toch niet ziek kan zijn. Evenzo kan men ziek zijn en zich toch gezond voelen. Er is misschien veel voor te zeggen om een aantal individuele gezondheids bevorderende voorzieningen (pillen, massages, enz.) niet te vergoeden. Ze bestaan echter wel en het gaat ze goed in de periferie van zorgland. Daar aan de grens met Welrijnië.

Het schort overigens niet alleen aan de definitie van gezondheid, maar ook aan die van ziekte. Niet elke weduwe krijgt "een cursus" van het RIAGG, niet ledere scheiding leidt tot psychotherapie, en niet elke hulpverlener van de Bijlmer bezoekt zijn huisarts met diffuse klachten. Het is, alle onderzoek bij elkaar genomen, redelijk aangetoond dat ernstige gebeurtenissen als verweduwing of een ramp meemaken, tot meer ziekte leiden. De samenhang is niet specifiek. Het. is zelden zo dat levensgebeurtenis $A$ een verhoogde kans op ziekte B oplevert, en vervolgen gebeurtenis C op ziekte $D$, enzovoort. Zo werkt die samenhang niet. Bij gezondheidsproblemen, ook bij sommige erkende aandoeningen, vindt men in de voorgeschiedenis wat meer levensgebeurtenissen dan men zou verwachten. De vraag die rijst is waarom verweduwing niet als een determinerende factor van een multiconditionele ziekte kan worden aangeduid, en gevaarlijke stoffen en micro organismen wel Men zou de gezondheidszorg natuurlik kunnen beperken tot de onomstotelijk bewezen A-leidt-tot-B-aandoeningen, maar in een Zorgland waar chronische ziekter $90 \%$ van de zlektelast in de samenleving uitmaken, ligt dat weinig voor de hand. Van veel van deze ziekten kennen we de oorzaken slecht, ook al kan men de gevolgen bestrijden en verlichten.

Op dit punt zorgt een ver doorgevoerde medische zuiverhelid woor nog enkele problemen. Het gaat namelijk niet alleen om al of niet vermeende oorzakelijke condities, 
maar ook om patienten met ernstige klachten die een moeizame weg door de gezondheidszorg gaan. ME, whiplash, RSI, bekkeninstabiliteil, hyperventilatie zijn voorbeelden van probleemzielkten. Bij een eerdere gelegenheid heb ik betoogd dat de door mij beschreven processen de mensen het recht op ziekelijkheid hebben ontnomen. Tot veel aandoeningen objectief vaststelbaar werden, waren vooral vrouwen aangewezen op een zeker recht op ziekelijkheid. Zij werden het zwakke geslacht geacht en verkeerden vaak in een weinig benijdenswaardige positie van een 24 -uursbelasting door de gebondenheïd aan huis, haard en echtgenoot. Hun afhankelijkheid was objectief en subjectief vaak groot. Bij het optreden van klachten kan dan de erkenning van 'een zwak gestel' soelaas bieden. Veel diffuse klachten anno 2000 zijn moderne varianten daarvan. In het kort verband van deze rede verklaar ik wellicht ten overvloede dat mijn redenering noch de mogelijke zwaarte noch de mogelijke gevolgen voor het dagelijks leven ontkent.

In Zorgland ligt de provincie Volksgezondheid. Het centraal bestuur wil er kennelijk minder geld en aandacht aan besteden. Bovendien kent het niet de precieze grenzen van het gebied met Welzijnië. Er moet emstig rekening worden gehouden met onlusten onder de inwoners van Klachten. In tegenstelling tot wat men in de hoofdstad soms schijnt te denken, bestaan zij echt. Mensen uit de streek Voiksgezondheid zullen binnenkort een petitie aanbieden teneinde het begrip gezondheid in ere te herstellen. Ze zullen ook een beroep op de minister doen als zij in haar

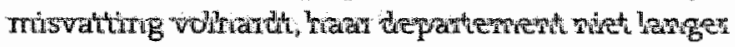
Volksgezondheid te noemen maar Afwezigheid var Zlekten.

\section{Verpleging en verzorging van patiènten thuis: de tweede stad van het land?}

Wanneer men in Zorgland nagaat waar de meeste bedrijvigheid plaats vindt, dan blijkt er naast de in de hoofd. stad geconcentreerde activiteiten, nog een tweede landstreek te bestaan wan min of meer zelfstandig uitgevoerde en veel gevragade werkzaamheden Het gaat om de verpleging en verzorging van patiënten met veelal chronische ziekten in 
hun eigen omgeving. Dat kan gewoon thuis zijn, maar ook gedaan worden in verzorgings -en verpleeghuizen, in categorale instellingen voor licharnelijke of psychische ziekten, in gezinsverzorgende woonvormen enz. De bedrijvigheid richt zich niet op de ziekte als aandoening; het gat om hulp bij lijden en klachten, maar vooral om hulp bij afhankelijkheid en ongemak. Bij al deze voorzieningen is de aandoening bijzaak geworden. Uiteraard is de aandoening erkend aanwezig. Zoals de verpleging en verzorging in het medisch centrum ten dienste staat van de behandeling, zo staat de behandeling in het zorgcentrum de verpleging en verzorging bij om effectief te kunnen werken. Zongcentrum? Bestaat er een zorgcentrum? Nee. De werzorging is, zoals al vastgesteld, gedecentraliseerd. Een interessante vraag is of er een tegenhanger kan bestaan van het medisch centrum. Eerst will ik alvorens daarop in te gaan het terrein nog verder in kaart brengen.

Een eerste constatering betreft het toegenomen belang van verpleging en verzorging. De dubbele vergrijzing en het toenemend aandeel van chronische ziekten in de ziektelast van de samenleving leidt tot een grotere vraag naar verzorging en verpleging. In principe honoreert zorgland die vraag ook. Wel treden fileproblemen op die men door de decentrale ligging van het wegenplan nauwelijks in kaart weet te brengen. Men probeert bovendien de verzorging zo veel mogelijk van de instellingen naar het eigen huishouden te brengen. Dat bevordert, zegt men, de autonomie van de patient en zijn naasten. Ook overwegingen van betaalbaarheid spelen hierbij een rol.

Een tweede constatering gaat over de ingewikkelde geschiedenis van de verpleegkunde in de afgelopen eeuw. Toen het medisch centrum nog voluit een instelling voor ziekenzorg was en de patienten er langdurig verbleven, hadden de ziekenhuizen een duale organisatie. De artsen hadden bedder op de afdelingen en deden polikliniek. De verpleegkundigen waren niet alleen bij de behandeling de verlengde arm van de arts, zij waren ook werantwoordelijk voor de dagelijkse gang van zaken in het ziekenhuis. De verpleegkundige directrice had een machtige positie. Na 1945 raakte de verpleging in de verdrukking door de moder- 
nisering wan de geneeskunde en het zlekenhuisbedrijf. De eerder geschetste ontwikkeling naar het medisch centrum makkte de verpleegkundige veel meer dan woorheen verlengde arm van de arts. Bovendien ontstonden door toegenomen arbeidsdeling allerlei paramedische beroepen. Tenslotte zorgde het verlangen naar efficient beheer ervoor dat de directrice van weleer gelijkwaardige diensten naast zich moest dulden. In de directiekamer bleven uiteindelijk. de arts en econoom over. Misschien was er nog plaats voor een verpleegkundige als adjunct directeur zorg. In de zestiger jaren zet een tegenbeweging in die weer voor meer aanzien van het beroep en vooral een betere scholing moest zorgen. Met vallen en opstaan lijkt het erop dat dit streven een goede kans van slagen heeft. Daarbij kon men aansluiw ten bij de onafhankelijke positie die de wijkverpleeg. kundigen, maar ook de gezinszorg, allang bezaten in de periferie van Zorgland.

Ir bestaat overigens een parallel met het beroep van huisarts dat in de vijftiger en zestiger jaren door hetzelfde diepe dal is gegaan. Het verlies aan aanzien en relevantie dat hen bedreigde door modemisering van de geneeskunde en het grotere bereik van de specialistische voorzieningen, was wellicht nog dramatischer. Niemand heeft ooit beweerd dat in Zorgland geen verpleegkundigen nodig zouden zijn. Bij huisartsen is wel de vraag gesteld of het geen uitstervend beroep betrof. Bij de huisartsen is de renaissance succesvol verlopen. Wellicht zelfs succesvoller dan bij de verpleegkundigen, omdat de huisartsen zich konden voegen in de ontwikkelingen die periferie en centrum in Aandoeningenland bij elkaar brachten

Nu terug naar de verpleging en verzorging. De teloorgang van de zorgende verpleegkunde in het ziekenhuis, gekoppeld aan de opkomst van technisch geschoolde, verlengde arm-verpleeglkundigen laat een van de vele onzekerheden zien in de vraag hoe op den duur het landschap van verpleging en verzorging er komt uit te zien. Tenminste ten aanzien van drie taakgebieden bestaat de turbulentie die bij nog niet stabiele verhoudingen behoren. Deze turbulentie betreft vooral de positie en het profiel van de hoger opge- 
leide functionarissen. Ik laat hierbij de positie van de verplegenden en verzorgenden buiten beschouwing. Daar gaat het vooral om arbeidsmarktproblemen.

- In het medisch centrum bestaat een grote behoefte aan gespecialiseerde verpleegkundigen. Daarnaast is er een lacune ontstaan op het gebied van wat ik met een lelijk woord zorg - of care management noem. Door de toegenomen medische zuiverheid is het noodzakelijk rond de individuele patiënt en ten behoeve van zorg aan groepen van patiënten een plan te maken van op elkaar afgestemde zorgactiviteiten. Transmurale verpleegkundigen -hoe verschillend ze ook worden aangeduidvullen thans de zorgvraag voor een deel op.

- In de centra voor de verpleging en verzorging vindt enerzijds een ontwikkeling plaats naar een eigen professionele identiteit met zaken als protocollen, standaarden en kwaliteitscontrole. Anderzijds is deze zorg onderwerp van bureaucratisering door sterk gereglementeerde indicatiestellingen en door op managementisme gestoelde neiging orn van zorgcentra productiebedrijven te maken. Met als het even kan een snufje marktwerking.

Voor het gehelle terrein van werzorging en verpleging geldt dat door de decentralisering en het gebrek aan regievoering het afstemmingsvraagstuk door alle partijen gevoeld wordt. Men kan zelfs stellen dat vooral bij de zorg voor de chronische patiënt thuis disease management en care management elkaar raken. Wiens werk is deze afstemming? De huisarts, de wijkverpleegkundige, een nieuwe zorgdeskundige, het breed samengestelde gezamenlijk overleg enzovoort. Voorlopig blijft de vraag onbeantwoord. Bovendien bestaat er een grensprobleem met buurland Familiezorg.

De situatie in de verzorging en verpleging is turbulent, niet persé verontrustend. De soms wat kwaadaardige tegenstellingen die we kennen uit de WAO-streek en wit klachtenland zijn hier afwezig. Voorspellen is lastig. Toch kan ik met behulp van mijn institutionalistische bagage wel enige lijnen uitzetten. In velden of sectoren zoals Zorgland 
werkt de Wet van het Isomorfisme, de gelijkwormigheid. In geval van dynamiek, en daar gaat het in de zorg over, zullen nieuwe manieren van organiseren de vorm aannemen van reeds succeswolle instituten. In de verpleegkunde woedt al heel lang de discussie in welke mate men het voorbeeld van de geneeskunde moet volgen. Het streven naar professionalisering, de oprichting van de HBO-V"s, de deskundigheids bevordering in eigen handen krijgen, de totstandkoming van de wet $B I G$, de verweterischappelijking van de discipline, het ontstaan van evidence based care, protocollen en standaarden, het accepteren dat er niveaus zijn binnen de verpleging en verzorging: het zijn allen voorbeelden van de Wet wan het Isomorfisme. Wel moet worden vastgesteld dat de volledige erkenning van de professie nog niet gerealiseerd is. Veel partijen in het veld van verpleging en verzorging geven nog de voorkeur aan bureaucratisering door het fijnregelen van de zorg in deeltaken en hun samenhang. Men kan ook in plaats daarvan stelselmatig kiezen voor 4 professionalisering van de zorg door op dezelfde wijze als bij de artsen veel over te laten aan een betrekkelijk kleine groep hoog opgeleiden.

Het scheppen van deze gelijkvormigheid in de vorm van een isomorfie van twee professies zou het meest stroken met de uitgangspunten van Zorgland. Verdere bureaucratisering van de verpleging en verzorging zal tot wanorde leiden, omdat zowel de kwaliteit van de zorg als de animo or daar te willen werken zullen verdwijnen.

Voor het ontstaan van een meer centrale professie ontbreekt echter op dit moment een belangrijke voorwaarde. Zou ooit een zorgcentrum kunnen ontstaan, dat in termen van isomorfie overeenkamstig is met het medisch centrum?. Daarmee ben ik terug bij mijn startvraag. Ik weet het antwoord niet. Toch valt niet uit te sluiten dat ook, geografisch en structureel gesproken, naast het medisch centrum (weer) een zorgcentrum ontstaat dat transmuraal werkt.

De provincie Verpleging en Verzorging is een gebied in sterke ontwikkeling. Over de groei van de activiteiten hoeft men zich geen zorgen te maken,. Hoe de huidige overdaad aan initiatieven de decentrale tendensen kan tegengaan, zal 
moeten bijken. Wil men echt ook de tweede hoofdstad van het Zorgland leveren, dan zal een niet all te grote groep inwoners zijn eigen kansen moeter grijpen.

\section{Het einde van de reis}

Aan het einde van deze korte reis door Zorgland houdt de reiziger gemengde ervaringen over. Over het gehele land ligt één samerhangende structurur van goede voorzleningen voor de behandeling van aandoeningen, gestuurd uit medische centra. Inderdaad een soort van 2 witserland, Denemarken of Nederland. Ook daar moet men overigens rekeningen houden met opstoppingen en met klein ongerief van soms minder gepast gedrag van hulpverleners en patienten. Komt men buiten deze voorzieningen terecht, dan kan men voor onverwachte ervaringen worden gesteld. Hier laat 跃 de beeldspraak verder los. Ik hoop dwidelijk te hebben gemaakt dat de ontwikkelingen in de gezondheldszorg gedurende de tweede helft van de vorige eeuw minder eenwoudig zijn geweest dan die schijnen te zijn in de ogen van wie gelooft in een lineaire, medisch-technische triomftocht. of men die nu positief of negatief beoordeelt. Ex vallen ook andere conclusies te trekken:

- Ziekte als verschijnsel blijft een mix van aandoening, klachten, ongemak en hulp zoeken hoe ingrijpend de positie van de aandoening ook is veranderd.

Arbeidsongeschiktheid als gevolg van aftankelijkheid en ongemak valt door de veranderingen in de zorg moeilijker vast te stellen. In het medische centrum van de zorg zou men in dit opzicht de medische zuiverheld minder sterk moeten door voeren. Daarnaast staat Nederland voor een moelijke taak. Het enige dat helpt is het terugdringen vam het aantal ziekmeldingen.

- Klachten bestaan echt, ook als de patiênt echt" niets mankeert. En zlektedefinitie die hieraan doet twijfelen, zal blijvend een bron van orust scheppen.

- De laatste vijftig jaar hebben een wederopstanding van de verpleegkunde en van de huisarts laten zien. Wat in de verdrukking kornt door modemisering, hoeft niet persé te verdwijnen.

- Het veld van de verzorging en verpleging van chronische en langdurige patienten thuis of in 
woonvoorzieningen zal in belang toenemen. De consequenties vain de decentralisatie van deze voorzieningen gekoppeld aan een structureel tekort aan coördinatie leidt tot instabiliteit die nog lang zal duren.

- Volgens de Wet van de Isomorfie lijkt het beter voor het "care management" te streven naar een met het 'disease management' vergelijkbare betrekkelijk kleine professie van verpleegkundigen/zorgdeskundigen dan de problemen in de verzorging en verpleging op te lossen door bureaucratisering en managementisme.

Tot slot misschien het belangrijkste wat ik vanmiddag wil zeggen. Ik heb zes en twintig jaar voor de Faculteiten Geneeskunde en Gezondheidswetenschappen gewerkt. Ik ga er vanuit dat ze ooit samen zullen gaan. Dat past bij alles wat ik betoogd heb. In dat geval hoop ik dat gezondheidswetenschappen blijft staan voor wat ik met anderen. gepoogd heb tot stand te brengen: een faculteit gericht op

so het gezond bestaan van mensen. Ik moet er niet aan denken dat ooit studenten Afwezigheid-van-ziekte-wetenschappen gaan studeren.

\section{Dankwoord}

Aan het einde van mijn officiële loopbaan gekomen past een persoonlijk woord. Op het moment waarop ik u toespreek neem ik gelukkig nog niet afscheid van mijn familie, buren, vrienden en kennissen. Ik verheug mij dat ze er zijn en ik hoop nog veel met hen mee te kunnen vieren. Daarbij maak ik één uitzondering. Ik verheug mij in het bijzonder over de arnwezigheid van mijn vader. Onze tijd biedt mensen zo nu en dan de gelegenheid in volle gezondheid de pensionering van kinderen mee te maken. Dat lijkt mij een voorrecht. Ik ben u zeer erkentelijk dat moeder en u het mij en mijn zusters hebt mogelijk gemaakt de sociale, culturele en intellectuele reis af te leggen, die vandaag nog niet ten einde is. U hebt dat gekund niet alleen door uw persoonlijke eigenschappen, maar ook door uw beider keuze, in de twintiger jaren van de vorige eeuw, voor een leven als bewuste sociaal democraten. Omdat u mede daar- 
door ook zelf de indertijd zogeheten maatschappelijke ladder hebt beklommen, hebt a het ons gemalkelijk gemaakt mee te klimmen. Ik ben daar trots op en dankbaar voor.

Dames en heren, op het moment waarop ik u toespreek ben ik ook niet van plan mijn intellectuele loopbaan af te sluiten Ik zal u daarom niet uiteenzetten hoe mijn vorming. is verlopen. Hooguit wil ik met erkentelijkheid vermelden, dat ik niet zou zijn wie ik ben zonder mijn gezin van herkomst, leraren van het Nederlands Lyceum in Den Haag, docenten en medewerkers van de Universiteit wan Amsterdam, en tenslotte bazen en collega's van het toenmalige Nederlands Instituut voor Preventieve gezondheidszorg TNO in Leiden.

Wie eenmaal hoogleraar is, vooral als dat op vrij jonge leeftijd gebeurt, maakt een vreernde ervaring mee die niet alleen positief is. Niemand vertelt je meer, wat men precies van je denkt, en of je het wel goed doet, behalve bij conflicten of in leuke sketches op afdelingsfeestjes. En van de weeromstuit zeg je ook weinig terug. Dit afscheid is daarom geschikt een paar dingen te zeggen die anders ongezegd zouden blijven.

Van de 26 jaar dat ik hoogleraar Medische Sociologie ben geweest ben ik merkwaardig genoeg nog niet de helft ervan fysiek in de groep aanwezig geweest. Dat klinkt raar en dat is het ook Als lid van het College van Bestuur. als decaan en als voorzitter van een andere capaciteitsgroep, raak je uit de buurt. Tegen het huidig gebruik in ga ik Medische Sociologie niet mijn excuses aanbieden. Misschien was alles anders gelopen; we zullen het nooit weten. Ik dark in de eerste plaats Riet Drop woor de samenwerking en alles wat ze voor de afdeling gedaan heeft; ik dank Jos Diederiks, Ronald. Knibbe en langer geleden Jan Boots woor hun aandeel in de leiding van de vakgroep; ik dank over de gehele periode in het bijzonder Jos Diederiks, Fred Stevens en Jouke van der Zee voor onze gezamenlijke wetenschappelijke arbeid; ik dank van de thans aanwezige bemensing Cees Schroër, Jan Joosten en Frans van der Horst voor een kwart 
eeww sociologische samenwerking en Majoke Arkenbout en sylva Welk voox de bijna even langdurige administratieve samenwerking en langer geleden Lenneke Wamars.

Met plezier denk lk terug aan de jaren van opbouw wan de groep Verplegingswetenschap. Op dit moment bezie ilk de stand van zaken lokaal en nationaal met een gemengd gevoel van zowel bezorgdheid als voldaanheid. Dat hoef ik jullie niet wit te leggen. In de tachtiget jaren is veel werk verzes door de pioniers Harry van der Bruggen, George Evers, Neeltye Mosterd, Hamie Smeets en Julie Rosier en wat later Anneke van dex Bergh-Braam, Ruud Halfens, Hanny Prick, Marian Tily en niet te vergeten de eerste generatie aio's.

Van mijn bestuurlijk werk heb ik al eerder afscheid genomen in 1998. $\mathbb{N k}$ houd het daarom kort. Ik zal personen bij name noemen. Achter elke naam gaan echter veel andere medewerkers schuil. Ik noem elke raam slechts één keer. Ik verzoelk tu derhalve goed op te letten. Uit kringen van het centraal bestuur bedank ik, gedenk ik soms, Sjeng, Harmen, Ton, Ben, Rob, Harry, Wijnand, Joep, Coen, Hans, Ad, Karl, Huub, Vic, Loek, Peter, Harry, Job, Marja, Huub, Ton, Arie, Rens, Paul en iedereen die daar achter staat.

Uit kringen van decanen en directeuren van de drie faculteiten waar ik heb gewerkt:

Om te beginnen, Co, en voorts Andre, Ed, Edward, Ferd, Foppe, Fred, Gerard, Gerjo, Gouke, Hans, Harold, Hein, Henk, Jan, Leo, Leon, Lieve, Louis, Paul, Roelof en Wil, en in hen alle anderen.

Uit kringen van de centrale diensten en stichtingen: Carina, Marjolein, Ellen, Albertine en heel kort Monica, natuurlijk Erik, René, Gerda, Mariët, Inge en Renée, niet te

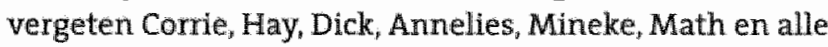
consulenten, en zo ook Marc, Han, Helmuth, Charles, Ger, Gerard, Nicole, Ted en al hun medewerkers.

Mocht $u$ uw naam niet hebben gehoord, dam is er sprake van hopelijk vergeeflijke nalatigheid. Ik heb weggelaten de vele collega's, en medewerkers van de faculteiten waar ik 
niet heb gewerlit en de diensten wamee ik net rechtstreeks te doen had. Zij kunnen zich inbegrepen achten. Evenzo heb ik mil beperkt tot de inteme namen. Buiten de deur ben ik vak geweest. Bij collega's en bestuurders van andere universitteiten, gemeenten en provincies, bij ministeries, raden en instellingen voor zorg en wetenschap. $\mathrm{k}$ zal dat zeker missen.

Zonder administratieve en secretariële bijstand ben ik niet veel waard. Wat de laatste jaren betreft had ik het net Kumnen stellen zonder Annie, Anouk, Carolien, Charlotte. Emilie, Ingrid, Joke, Jose, Len, Mariette, Marjo, Patrice, Petra, Rhona, Severine en Tiry, maar vooral niet zonder in de volgorde waarin zij rechtstreeks voor mij werkten Geesje, Thresy en Dieuwke.

Deze plechtigheid kon worden gehouden door de inspanningen van Dieuwke en Lilian, Patrice, Len, Emilie en Marjoke en door het prima werk van Frits Timmers, Guus van Rooy en hum mensen.

Ik heb met animo aan de Universiteit Maastricht rondgelopen, graag onderwezen, net plezter onderzocht, met voldoening promovendi begeleid, met genoegen bestuurd en met vreugde geinternationaliseerd.

Ik heb gezegd. 


\section{Literatuur in volgorde van vermelding}

1. Over centrun en periferte.

E. Shils, Center and Periphery, Essays in Macrosociology, Chicago 1975

PI. DiMaggio en WW. Powell, The Iron Cage Revisited: Institutional Isomorphism and Collective Rationality $63-82$ in W.W. Powell en PJ. DiMaggio (ed) The new Institutionalism in Organizational Analysis Chicago/London 1991

W.R. Scott en I.W. Meyer. The Organization of Socletal Sectors: Propositions and Early Evidence $108-143$ in Powell en DiMaggto, 1991

2. H.A.M. Ruhe, Een huisartsenpraktijk in 1938 en 1954, Assen 1957

3. I. Widdershoven-Heerding, Geneeskunde als wetenschap. Wetenschapsidealen in de Nederlandse Geneeskunde van 1840 tot 1970 .

Daarim: op p. 184 een citat uit: L.L Conrad, M. Neve, V. Nutton, R.Porter, A.Wear. The Westem medical tradition: $800 \mathrm{BC}-1800 \mathrm{AD}$ Cambridge 1995

4. R. Prins, Sickness absence in Belgium, Germany (PR) and the Netherlands. A Comparative study. Proefschrift UM 1990

B. Cuelenaere, T. Veserman, R. Prins, A.M. van der Giezen. In distant mirrors. Work incapicity and return to work, Zoetermeer: College van Toezicht Sociale Verzekeringen 1999.

5. Wetenschappelijke Raad voor het Regeringsbeleid, Volksgezondheidszorg, Den Haag 1997

6. Deze rede is geen zelfplagiant, wel is geput uit eigen publicaties vanat mijn proefschrift Afwezigheid wegens ziekte uit 1968. 